\title{
Capital management using stock sales
}

Reza Mohammadi ${ }^{1}$

[Department of Accounting group, Kerman Unit, Islamic Azad university, Kerman .Iran]

Email : reza.co.us@gmail.com

\begin{abstract}
Based on a large sample of publicly listed and non-listed US commercial banks from 1996 to 2011, we find robust evidence consistent with banks using realized available for sale (AFS) securities gains and losses to smooth earnings and increase low regulatory capital. We also find that (i) banks with positive earnings smooth earnings, and banks with negative earnings generally take big baths; (ii) regulatory capital constrains big baths; (iii) banks with more negative earnings and more unrealized beginning-of-quarter losses (gains) take big baths (smooth earnings); and (iv) banks with low regulatory capital and more unrealized gains realize more gains. Also, banks with negative earnings tak big baths (avoid or reduce the earnings loss) if their unrealized gains are insufficient (sufficient) to offset the negative earnings. Our inferences apply to listed and non-listed banks, which indicates that the earnings management incentives do not derive solely from public capital markets. Our findings reveal that the accounting for AFS securities gains and losses enables banks to manage regulatory capital and earnings in a variety of ways.
\end{abstract}

Keywords: Available for sale securities, Realized gains and losses, Regulatory capital

\footnotetext{
${ }^{1}$ Reza mohammadi, Accounting group, Kerman Unit, Islamic Azad university, Kerman , Iran Email:reza.co.us@gmail.com
} 


\section{Introduction}

The question we address is the extent to which, and how, banks use available for sale (AFS) securities realized gains and losses to manage earnings and regulatory capital. ${ }^{2}$ AFS securities is the largest category of banks' securities and a sizable portion of bank assets. We base our inferences on a large sample of publicly listed and non-listed US commercial banks from 1996 to 2011. Our findings reveal that both types of banks use realized gains and losses on AFS securities to manage earnings and regulatory capital in a variety of ways. We find that banks realize gains and losses to manage regulatory capital and smooth earnings, avoid losses, or take a big bath, and that the choice depends on the circumstances, including the extent to which the banks have unrealized gains and losses to realize. Thus, our findings reveal that banks opportunistically use the discretion afforded to them by accounting standards and regulatory requirements that exclude unrealized securities gains and losses from earnings and regulatory capital.

Accounting Standards Codification (ASC) Topic 320 (formerly Statement of Financial Accounting Standards No. 115, FASB 1993) created AFS securities and specified a new accounting treatment for them. Prior to ASC 320, investment securities, which represented most bank securities, were measured at amortized cost. Although investment securities fair values were disclosed, there was no recognition on the statement of financial position or income based on those fair values. The investment securities gains and losses were recognized in earnings only when they were realized. ASC 320 specifies that AFS securities be measured at fair value, with changes in fair value recognized in other comprehensive income, not earnings. Thus, the pre-ASC 320 scope for banks to manage earnings by selectively realizing securities gains and losses is unchanged by ASC 320, presuming managers view net income as the earnings management target. However, if bank managers view comprehensive income as the target, we will not observe evidence of selective selling.

behavior. As with investment securities, AFS securities gains and losses generally affect regulatory capital only when they are realized.

We base our inferences on the relation between realized gains and losses on AFS securities and earnings and regulatory capital, each before the effect of the gains and losses (henceforth earnings and regulatory capital), and control variables identified in prior research. We obtain data from quarterly bank regulatory reports, which

${ }^{2}$ We use the terms Bearnings^ and Bnet income ${ }^{\wedge}$ interchangeably. 
include detailed information about banks' securities and regulatory capital. These reports cover publicly listed and non-listed banks. Our sample comprises 136,879 bank-quarter observations for 6300 banks, with 15,204 (121,675) observations for 728 (5862) listed (non-listed) banks.

We begin by focusing on the use of realized AFS securities gains and losses to smooth earnings and increase regulatory capital. Consistent with earnings smoothing, we find a robust, significantly negative relation between earnings and realized AFS securities gains and losses. Consistent with banks' incentives to increase low regulatory capital, we find that banks with low regulatory capital realize significantly more net gains than other banks. Prior research on investment securities implies these inferences. Although we do not find that banks with low regulatory capital smooth earnings more or less than other banks, the findings are based on tests that do not distinguish banks with positive and negative earnings, which could mask offsetting differences between earnings smoothing and big bath earnings management.

We next test for big bath earnings management by permitting the relation between realized gains and losses on AFS securities and earnings to differ for banks with positive and negative earnings. We find evidence of earnings smoothing by banks with positive earnings and of big baths by banks with negative earnings. We also find that banks with low regulatory capital and negative earnings engage in less big bath earnings management, which indicates that regulatory capital requirements constrain big bath earnings management.

We exploit disclosed beginning-of-quarter accumulated unrealized gains and unrealized losses on AFS securities to take into consideration the extent to which a bank has the opportunity to realize gains or losses to manage earnings and regulatory capital. We find that banks with negative earnings take big baths to a greater extent when they have more unrealized losses, and engage in earnings smoothing to a greater extent when they have more unrealized gains. We do not find that banks with positive earnings smooth earnings more when they have more unrealized losses. We find that banks with unrealized gains insufficient to convert negative earnings into positive earnings take big baths. However, we also find that some banks avoid negative earnings by realizing just enough securities gains to avoid a loss, and that others reduce the loss even if they do not avoid it.

Estimating the relations separately for publicly listed and non-listed banks reveals that our inferences generally apply to both types of banks. However, some findings 
are more pronounced for listed banks. In particular, we find that listed banks with positive (negative) earnings smooth earnings (take a big bath) to a greater extent than

non-listed banks, and that listed banks with low regulatory capital realize more net securities gains. Regardless, our findings reveal that incentives to manage earnings and regulatory capital are not limited to banks whose equity trades in public capital markets.

Findings from additional analyses support our inferences. First, our inferences are unaffected by simultaneously considering loan loss provisions, securitization gains, and changes in equity financing as alternative earnings and regulatory capital management tools. Second, as expected, we find no evidence that banks use fair value gains and losses on trading securities to smooth earnings or increase low regulatory capital. Third, using banks' median earnings before taxes in the quarter as the earnings benchmark reveals similar evidence of earnings management. Fourth, we find that earnings smoothing by non-listed banks stems primarily from incentives associated with depositors.

We contribute in several ways to prior research on banks using realized securities gains and losses to smooth earnings and regulatory capital. This prior research almost exclusively is based on the period before ASC 320 and employs samples considerably smaller and less diverse than ours. We build on this research by finding strong and robust evidence consistent with banks using realized AFS securities gains and losses to smooth earnings and manage regulatory capital. We extend this literature by finding that the extent to which banks smooth earnings and manage regulatory capital depends on the extent to which the banks have unrealized securities gains and losses to realize.

We also provide evidence consistent with banks using realized AFS securities gains and losses to manage earnings in ways other than to smooth earnings. In particular, we find that banks with negative earnings take big baths (reduce the loss), particularly when they have more unrealized AFS securities losses (gains), and that banks engage in less big bath earnings management when they have low regulatory capital.

The remainder of the paper proceeds as follows. Section 2 discusses the institutional background and related research, which provide the basis for our empirical predictions. Section 3 develops the research design. Section 4 describes the data, and Section 5 presents the results. Section 6 offers a summary and concluding remarks. 


\section{Institutional background and related research}

\subsection{Available for sale securities}

The accounting for investment securities in the US is specified in FASB Accounting Standards Codification (ASC) Topic 320. Prior to ASC 320, banks classified securities as trading or investment. Trading securities, which typically represented a small fraction of bank assets (Barth 1994), were securities the bank intended to trade

actively, and were measured at fair value with changes in fair value recognized in earnings. Investment securities, which represented most bank securities, were debt securities the bank had the ability and intent to hold to maturity, and were measured at amortized cost. Although the fair value of investment securities was disclosed, there was no accounting recognition on the statement of financial position or income based on those fair values; only realized gains and losses were recognized in earnings and equity. ${ }^{3}$

ASC 320 requires all entities, including banks, to categorize securities into one of three categories. Trading securities, the first category, are securities that the bank plans to sell in the near term; this category was largely unchanged by ASC 320 . Heldtomaturity (HTM) securities, the second category, are debt securities that the bank has the positive intent and ability to hold to maturity. Although this description is similar to that of investment securities, the classification criteria in ASC 320 are more stringent. Most notably, ASC 320 introduced Btainting rules, ${ }^{\wedge}$ under which sales of HTM securities could taint the bank's assertion that it had a positive intent to hold the securities to maturity, thereby precluding the bank from using the HTM category. The third category is available for sale (AFS). AFS securities are securities other than those categorized as trading and held to maturity. Shortly after ASC 320 became effective, the FASB offered a brief reclassification period during which banks could reclassify securities from HTM, i.e., securities previously classified as investment securities, to AFS (FASB 1995). Most banks did so. ${ }^{4}$ As a result, AFS replaced investment securities as the largest category of banks' securities.

Unlike investment securities, AFS securities are measured at fair value. However, unrealized AFS securities gain sand losses are recognized in other comprehensive income.

\footnotetext{
${ }^{3}$ Securities held for sale were measured at the lower of cost or market. Held-for-sale securities comprised a small fraction of banks' securities.

${ }^{4}$ Untabulated statistics based on our sample banks reveal that during this reclassification period, for approximately $80 \%$ (69\%) of publicly listed (non-listed) banks the increase in AFS securities, as a percentage of total securities, was within $1 \%$ of the decrease in HTM securities.
} 
These gains and losses are only recognized in earnings when they are realized, i.e., when the security is sold or otherwise disposed of, or when impairment is deemed other-than temporary. That unrealized gains and losses on AFS securities do not affect earnings motivates the prediction that bank managers selectively sell or otherwise dispose of these securities to manage earnings. However, if bank managers view comprehensive income as the earnings management target, we will not observe evidence of this strategic selling behavior. Unrealized gains and losses (gains) on AFS debt (equity) securities are excluded from Tier 1 regulatory capital and thus affect regulatory capital only when realized. ${ }^{5}$ Therefore, realizing unrealized gains or losses.

largely determines when the gains or losses are included in regulatory capital as well as earnings.

Our tests focus on realized gains and losses on AFS securities. Trading securities are measured at fair value, with changes in fair value, including unrealized gains and losses, recognized in earnings and regulatory capital. Thus, there is no incentive to realize trading securities gains and losses to manage earnings or regulatory capital. Because HTM securities are measured at amortized cost, realizing gains and losses on HTM securities affects earnings. However, selling HTM securities risks violating the tainting rules, which means that banks are unlikely to use these realized gains and losses to manage earnings or regulatory capital.

Realizing securities gains and losses is a potentially attractive way to manage earnings and regulatory capital because it could be less costly than managing accruals or engaging in other real earnings management activities. ${ }^{6}$ Although securities sales involve transactions costs, such sales are not as subject to ex post scrutiny-such as from auditors - as accruals because there is a transaction. Such scrutiny is costly and, coupled with accounting rules, limits the extent to which banks can manage accruals. Although the extent to which a bank can realize AFS securities gains and losses is limited by the extent to which the bank has unrealized gains and

\footnotetext{
${ }^{5}$ The regulatory treatment for unrealized AFS securities gains and losses is the same as for investment securities prior to ASC 320 . This treatment was unchanged during our sample period, except that starting in 1998 banks are permitted, but not required, to include in Tier II capital $45 \%$ of unrealized gains on AFS equity securities. Untabulated statistics based on our sample banks reveal that the percentage of AFS equity securities is small; the median is zero and the 75th percentile is < 1\%. Under Basel III, which became effective in 2014 after the end of our sample period, accumulated other comprehensive income is included in Tier 1 capital for some banks. Its inclusion is mandatory for banks that use the advanced approach in measuring risk-weighted assets; these typically are large banks, but other banks have a one-time opportunity to opt out of this requirement.

${ }^{6}$ Real earnings management involves managing earnings by entering into transactions that are reflected in financial reporting (Goel and Thakor 2003). Graham et al. (2005) reports results of a survey of chief financial officers that indicate real earnings management is more prevalent than accruals-based earnings management. ${ }^{6}$ Untabulated statistics reveal that, on average, banks classify $86 \%$ of non-trading securities as AFS, which represents $17 \%$ of total assets. Although trading securities represents $15 \%$ of total assets for the ten largest bank holding companies, it represents less than $0.06 \%$ for other banks; only $3 \%$ sample banks have trading securities.
} 
losses to realize, realizing AFS securities gains and losses avoids costs associated with accruals-based earnings management.

Opportunistically realizing securities gains and losses can affect earnings and regulatory capital to an economically meaningful extent. Nissim and Penman (2007) and Laux and Leuz (2010) report that banks classify 95\% of non-trading securities as AFS, which represents $16 \%$ of total assets. Although trading securities represent more than $12 \%$ of total assets for the largest bank holding companies, they represent nearly $0 \%$ of total assets for the majority of banks. ${ }^{6}$

2.2 Related research on earnings management in banks.

The literature on earnings management is extensive and offers several incentives for listed firms to manage earnings, such as smoothing earnings (e.g., Healy and Wahlen 1999; Dechow et al. 2010b), managing earnings relative to a target (e.g., Burgstahler and Dichev 1997; Degeorge et al. 1999), and recognizing large losses when a loss is unavoidable to increase the likelihood of positive earnings in the future, i.e., taking a big bath (see, e.g., Dechow et al. 2010a for a review). Coppens and Peek (2005), Graham et al. (2005), Burgstahler et al. (2006), and Hope et al. (2013) reveal that non-listed firms also perceive earnings management as important. All of these incentives apply to banks. In addition, banks are subject to regulatory capital requirements; thus, banks with low regulatory capital have an incentive to increase it or at least not decrease it substantially. As a result, banks could manage earnings to accomplish that objective. Beatty and Liao (2014) provides a review of the large empirical literature on the banking industry, including that addressing earnings management.

Banks' use of realized securities gains and losses to smooth earnings has been a topic of accounting research for at least 25 years. The findings from this literature suggest that banks engage in this smoothing behavior, but the findings are not consistently robust. Barth et al. (1990) finds that investors price annual realized securities gains and losses as if they perceive that bank managers time the gains and losses to offset losses and gains in other earnings. See also Ahmed and Takeda (1995) and Warfield and Linsmeier (1992). Beatty et al. (1995) finds that banks smooth earnings using miscellaneous gains and losses, which includes gains and losses on fixed assets, loans, and credit card portfolios in addition to realized securities gains and losses. However, the association between earnings and miscellaneous gains and losses is not significant when the estimation equation includes bank fixed effects. Collins et al. (1995) also finds that banks use realized securities gains and losses to smooth earnings, although not consistently across 
specifications. These studies base their findings on samples of 638- 3256 observations between 1969 and 1991 from the 150 largest bank holding companies. Beatty and Harris (1998, BH) investigates differences in earnings smoothing for listed and non-listed banks using a sample of 778 bank-year observations from 1991 and 1992, 265 (513) of which are from listed (non-listed) banks. BH finds that both types of banks engage in earnings smoothing using realized securities gains and losses, but that listed banks do so to a greater extent. BH also reports evidence that listed banks use this earnings smoothing to convey information to investors regarding next quarter's earnings. ${ }^{7}$ Using a sample of 1867 listed and nonlisted banks from 1988 to 1998, Beatty et al. (2002) adopts the research design of Burgstahler and.

Dichev (1997) and finds that listed banks are more likely than non-listed banks to use realized securities gains to eliminate small earnings decreases. ${ }^{8}$

To our knowledge, the only published study reporting evidence of banks using realized AFS securities gains and losses to smooth earnings is Lifschutz (2002), which is based on 1408 bank-quarter observations from 1997 to 2000 for 88 bank holding companies with total assets exceeding \$5 billion. Lifschutz (2002) estimates the relation between (i) the ratio of realized securities gains and losses to total value of AFS securities, and (ii) return on equity or return on assets. Based on reported significant negative coefficients on each performance measure, Lifschutz (2002) concludes that the motivation of managers of these banks to manage earnings by realizing securities gains and losses is negatively related to bank earnings before realized gains and losses. However, Lifschutz (2002) neither corrects the reported tstatistics for serial and cross-sectional correlation in regression residuals nor includes bank fixed effects in the estimation equation. Untabulated statistics based on our efforts to replicate the findings in Lifschutz (2002) reveal that the findings in that study are not robust to incorporating either of these design features, which suggests that the tests in the study do not support its conclusion. ${ }^{9}$

\footnotetext{
${ }^{7}$ Dong et al. (2014) examines the equity pricing implications of realized AFS securities gains and losses for listed banks by estimating the relation between the gains and losses and next quarter's earnings. The study finds that the gains and losses help predict earnings, but does not consider implications of earnings management for predictive ability.

${ }^{8}$ Several studies investigate whether banks use the loan loss provision to smooth earnings. See Wall and Koch (2000) for a summary of this literature. More recently, Kilic et al. (2013) finds that adoption of SFAS 133, which reduces banks' ability to use derivatives to smooth earnings, is associated with increased use of the loan loss provision to smooth earnings. Some studies find that banks use the loan loss provision to manage regulatory capital (Moyer 1990; Beatty et al. 1995; Ahmed et al. 1999; Pérez et al. 2008). Other studies find that banks use gains on asset securitizations to manage earnings (Karaoglu 2005; Dechow and Shakespeare 2009; Dechow et al. 2010b). Section 5.5.1 considers whether simultaneous use of the loan loss provision and securitization gains to manage earnings and regulatory capital affects our inferences.

${ }^{9}$ The research design details in Lifschutz (2002) are insufficient to replicate that study's analysis. For example, Lifschutz (2002) defines return on assets as Bprofitability to assets of income before tax and before net gains. ${ }^{\wedge}$ We assume income is net income before taxes and realized AFS securities gains and losses, which is the definition we use, and assets is end-of-quarter total assets. We follow Lifschutz's (2002) sample construction
} 
Regarding regulatory capital, Moyer (1990) finds evidence consistent with banks using realized securities gains and losses to increase regulatory capital, but only for. banks with regulatory capital below the minimum. ${ }^{10}$ Scholes et al. (1990) finds a significant negative relation between banks' regulatory capital and realized securities gains and losses, which suggests that banks use realized securities gains and losses to smooth regulatory capital. ${ }^{11}$ Beatty et al. (1995) finds a negative relation between. miscellaneous gains and losses and regulatory capital, although the relation is not significantly negative in all specifications. Collins et al. (1995) finds that after 1980 realized securities gains and losses are not consistently negatively related to regulatory capital.

Taken together, prior research suggests banks use realized securities gains and losses to smooth earnings and manage regulatory capital. We revisit this question using data from quarterly bank regulatory reports for all publicly listed and nonlisted banks, which enables us to conduct our tests-including those relating to differences between listed and non-listed banks-on a considerably larger sample with greater crosssectional variation. These features of our sample could enable us to provide more robust evidence than was possible in prior research.

In addition, financial reporting by banks has changed since the time of this prior research, which could alter banks' earnings and regulatory capital management ability and incentives. Most notable is the change from not recognizing unrealized securities gains and losses - prior to the issuance of ASC 320-to recognizing them in other comprehensive income. Prior research provides a basis for expecting that this change could reduce bank managers' perceived benefits from using realized AFS securities gains and losses to manage earnings. For example, several studies find that other comprehensive income, particularly the unrealized securities gains and losses component, is value relevant (e.g., Dhaliwal et al. 1999; Biddle and Choi 2006; Chambers et al. 2007; Bamber et al. 2010). Except for Dhaliwal et al. (1999), the sample periods in these studies are after the issuance of ASC 220 in 1997 (formerly

as we understand it, except that we retain banks without complete data for all 16 quarters; doing so is necessary to replicate the significant negative coefficients on the performance measures. Our procedures result in 1471 observations for 117 banks and a t-statistic associated with return on assets (equity) of $-1.91(-2.30)$, which would support the conclusion in Lifschutz (2002). However, clustering residual standard errors by bank and yearquarter when constructing t-statistics reveals an insignificant relation; the t-statistic for the return on assets (equity) coefficient is -0.75 ( -0.95 ). Including bank fixed effects in the estimation equation reveals either a significant positive relation or an insignificant relation, depending on whether we also double-cluster residual standard errors. The t-statistic for the return on assets (equity) coefficient is 2.93 (1.73) without also doubleclustering standard errors, and 1.58 (1.02) with double-clustered standard errors. None of these statistics support the conclusions in Lifschutz (2002).

${ }^{10}$ Few bank-quarter observations have regulatory capital below the required minimum. See footnote 13 . Thus, the incentive to avoid violating minimum regulatory capital requirements largely is not present in our sample.

${ }^{11}$ Scholes et al. (1990 SWW) also finds a significant negative relation between realized securities gains and losses and the loan loss provision. Although SWW interprets this finding as meaning banks use realized securities gains and losses to smooth earnings by offsetting the earnings effect of the loan loss provision, SWW does not provide evidence directly supporting this interpretation. 
Statement of Financial Accounting Standards No. 130; FASB 1997), which led to more prominent disclosure of the components of other comprehensive income. Hirst and Hopkins (1998) shows that more prominent presentation of other comprehensive income decreases the tendency for firms to manage earnings.

In a concurrent working paper, Dong and Zhang (2015) examines the selective trading of AFS securities by publicly traded US commercial banks after implementation of ASC 320. Consistent with our findings, Dong and Zhang (2015) finds evidence that banks realize gains and losses on AFS securities to smooth earnings and meet or beat earnings benchmarks. However, that study's focus is on why ASC 320 fails to inhibit this behavior. The study finds that the earnings management primarily occurs in banks that disclose unrealized gains and losses in the statement of shareholders' equity rather than in a separate statement of comprehensive income or below net income in the income statement, which the study posits as providing more prominent disclosure. The study interprets this finding as consistent with managers believing disclosure location affects financial statement users' attention to disclosed information.

Our large sample, with its attendant large cross-sectional variation, also permits us to consider other earnings management incentives that prior research does not consider. In particular, we can address the following, heretofore unaddressed,

questions: Do the earnings management and regulatory capital incentives interact? Does banks' use of realized gains and losses on AFS securities to smooth earnings and manage regulatory capital depend on their opportunity, i.e., the extent to which the banks have accumulated unrealized AFS securities gains and losses to realize? Do banks with negative earnings use realized AFS securities losses and gains to engage in big bath earnings management or to avoid losses? Is big bath earnings management less evident for banks with low regulatory capital? Does accumulated unrealized AFS securities losses (gains) reveal the opportunity that banks with positive (negative) earnings have to engage in earnings smoothing or the opportunity that banks with negative earnings have to take a big bath? And do all of these findings apply to listed and non-listed banks? We find evidence consistent with the answer to each question being Byes.^

\section{Research design}

3.1 Earnings smoothing and increasing regulatory capital 
We begin by estimating Eq. (1) to determine whether banks use realized gains and losses on AFS securities to smooth earnings and whether banks with low regulatory capital realize more gains. We also test whether these incentives interact. ${ }^{12}$

$$
\begin{aligned}
& R G L_{i t}=\beta_{I} N_{i t}+\beta_{2} \operatorname{RegCapLow}_{i t}+\beta_{3} N_{i t} \times \operatorname{RegCapLow}_{i t}+\gamma_{I} U L_{i t-l}+\gamma_{2} U G_{i t-l} \\
& +\gamma_{3} \text { Size }_{i t}+\gamma_{4} \text { Liquid }_{i t}+\gamma_{5} \text { Sec it }+\gamma_{6} \text { VIX }_{t}+\gamma_{7} \text { Unemp }_{t}+\gamma_{8} \text { LIBOR }_{t}+\varepsilon_{i t}
\end{aligned}
$$

RGL is realized gains and losses on AFS securities and $\mathrm{NI}$ is net income before taxes and RGL, both deflated by beginning-of-quarter total assets. RegCapLow is an indicator variable that equals one if the bank's regulatory capital ratio-which bank. regulators define as allowable Tier 1 plus allowable Tier 2 regulatory capital, deflated by riskweighted assets - before RGL and after taxes, is in the lowest decile for the quarter, and zero otherwise. ${ }^{13} \mathrm{i}$ and $\mathrm{t}$ denote bank and quarter. Equation (1), and all equations that follow unless otherwise stated, include bank fixed effects and employ residual standard errors clustered by bank and year-quarter to construct tstatistics (Petersen 2009; Gow et al. 2010).

If banks use AFS securities to smooth earnings, we predict that the NI coefficient, $\beta_{1}$, is negative, and if banks with low regulatory capital realize more gains, we predict that the RegCapLow coefficient, $\beta_{2}$, is positive. The predicted sign for the $\mathrm{NI} \times$ RegCapLow coefficient, $\beta_{3}$, depends on whether earnings smoothing is dominated by positive or negative $\mathrm{NI}$ banks. If earnings smoothing is dominated by positive (negative) NI banks recognizing more (fewer) losses or fewer (more) gains, then we predict that $\beta_{3}$ is positive (negative). Banks with low regulatory capital have incentives to realize more gains, regardless of $\mathrm{NI}^{\prime} \mathrm{s}$ sign, which mitigates (reinforces) incentives for banks with positive (negative) NI to realize more (fewer) losses and fewer (more) gains.

Equation (1) includes four variables as controls for bank characteristics likely associated with realized gains and losses on AFS securities. $U_{L_{t-1}}\left(U_{G_{t-1}}\right)$ is accumulated unrealized AFS securities losses (gains) at the beginning of the quarter. We expect that banks with more beginning-of-quarter accumulated unrealized losses

\footnotetext{
${ }^{12}$ For ease of exposition, we use the same notation for coefficients and error terms in each equation. ${ }^{13}$ We use the lowest decile because only 1012 observations relating to 300 banks, of 136,879 observations for 6300 banks, have regulatory capital before RGL and after taxes, RegCap, less than the required level of $8 \%$. Because violating regulatory capital is a serious matter for banks, most maintain a buffer above the required minimum, which is unobservable (Amel-Zadeh et al. 2017). Thus, what level to use is an empirical matter. Untabulated statistics reveal that mean RegCap in the lowest decile, i.e., those observations for which RegCapLow equals one, is $10 \%$, whereas the mean in the highest decile is $45 \%$, which largely is attributable to some banks holding assets with low risk weights. Untabulated findings also reveal that using the lowest two or lowest five deciles reveals inferences consistent with those revealed by the tabulated results. However, the significance levels are somewhat lower for the tabulated results, which supports the empirical validity of using the lowest decile.
} 
(gains) are more likely to realize losses (gains) during the quarter (Scholes et al. 1990; Beatty and Harris 1998). Size is the natural logarithm of beginning-of-quarter total assets. Liquid is liquid assets (Beatty et al. 1995), which is the sum of cash items in process of collections, balances due from banks in foreign countries and foreign central banks, currency and coin, balances due from depository institutions in the US, and balances due from Federal Reserve Banks. Sec is the sum of held-tomaturity, available-for-sale, and trading securities. UL, UG, Liquid, and Sec are deflated by beginning-of-quarter total assets. Because securities gains and losses likely depend on economic conditions, Eq. (1) includes macroeconomic control variables: VIX, S\&P 500 Index options implied volatility; Unemp, the one-yearahead consensus forecast of the US unemployment rate; and LIBOR, the difference between the London Interbank Offer Rate and overnight indexed swap rates. These variables are quarterly, which eliminates the need to include quarter fixed effects. ${ }^{13}$

\subsection{Big baths and the opportunity for managing earnings and regulatory capital}

We next estimate Eq. (2), which expands Eq. (1) by separating negative and positive $\mathrm{NI}$ banks. This separation permits us to test whether banks with negative NI take a big bath and banks with positive NI smooth earnings. ${ }^{14}$ As in Eq. (1), we expect banks with low regulatory capital to realize more gains. Equation (2) also permits us to test whether these relations are more pronounced when banks have more opportunity to respond to these incentives, i.e., when they have more accumulated unrealized gains or unrealized losses on AFS securities, depending on the incentive. We also test whether the incentives to manage earnings and regulatory capital interact, particularly whether the incentive for banks with low regulatory capital to recognize gains mitigates the incentive for banks to take a big bath.

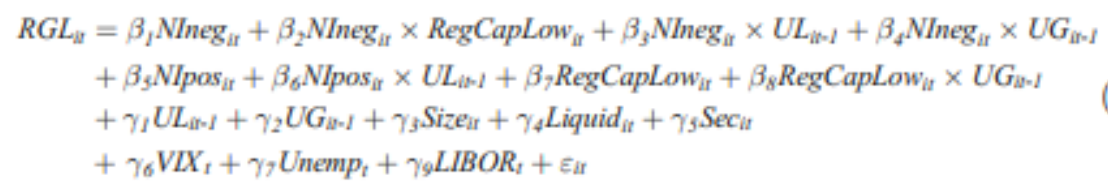

\footnotetext{
${ }^{13}$ In untabulated analyses we alternately include, in all specifications, four proxies for growth -changes in total interest income and total assets between the current quarter and one and four quarters prior. We do not include these variables in the tabulated findings because their construction results in a loss in sample size.

${ }^{14}$ We define Bbig bath^ earnings management as banks with more negative earnings before realized AFS securities gains and losses realizing more losses or fewer gains. We do not define it as only realizing more losses, as is common in the accruals-based earnings management literature, because realizing AFS securities gains and losses to manage earnings is a type of real earnings management with direct cash flow implications. Negative accruals recognized to achieve big bath earnings management reverse in future periods, which is not the case for realized securities losses. Rather, we expect banks with negative earnings that sell AFS securities to select securities with unrealized losses or with smaller unrealized gains, thereby enhancing their ability to realize larger gains in future periods.
} 
NIneg (NIpos) is $\mathrm{NI}$ if $\mathrm{NI}$ is less than (greater than or equal to) zero, and zero otherwise.

If banks with negative $\mathrm{NI}$ take a big bath (smooth earnings), we predict that $\beta_{1}$ is positive (negative). Low regulatory capital provides incentives to realize more gains, which mitigates the incentive for negative NI banks to take big baths. Thus, Eq. (2) includes NIneg $\times$ RegCapLow, and we predict that $\beta_{2}$ is negative. Because there is more opportunity for big bath earnings management when negative NI banks have more accumulated unrealized losses, Eq. (2) includes NIneg $\times U L_{t-1}$, and we predict that $\beta_{3}$ is negative. Because there is more opportunity for earnings smoothing when negative (positive) $\mathrm{NI}$ banks have more accumulated unrealized gains (losses), Eq. (2) includes NIneg $\times U G_{t-1}$ and NIpos $\times U L_{t-1}$, and we predict that $\beta_{4}\left(\beta_{6}\right)$ is negative (positive). ${ }^{15}$ Because there is more opportunity to realize gains to increase regulatory capital when the bank has more accumulated unrealized gains, Eq. (2) includes RegCapLow $\times \cup G_{t-1}$, and we predict $\beta_{8}$ is positive. All other predictions are as in Eq. (1).

\subsection{Avoiding losses}

We next test whether banks realize securities gains to avoid losses, because loss avoidance is a prominent earnings management objective (e.g., Burgstahler and Dichev 1997; Beatty et al. 2002; Dechow et al. 2010a) and is a benchmark available for both listed and non-listed banks. In particular, we estimate Eq. (1) without the interaction terms separately for observations with (i) $\mathrm{NI}>=0$, (ii)

$\mathrm{NI}<0$ and $\mathrm{NI}+\mathrm{UG}<0$, and (iii) $\mathrm{NI}<0$ and $\mathrm{NI}+\mathrm{UG}>=0$. We omit the interaction terms because we estimate the equation separately for positive and negative $\mathrm{NI}$ and use UG in our partitioning criteria. Because banks in the first group have positive NI, we predict that they smooth earnings, i.e., we predict that $\beta_{1}$, the $\mathrm{NI}$ coefficient, is negative. Banks in the second group have negative $\mathrm{NI}$, but have insufficient beginning-of-quarter UG to enable them to attain positive net income after realizing securities gains. Thus, we predict that they take a big bath, i.e., that $\beta_{1}$ is positive. Banks in the third group also have negative NI, but have sufficient UG to enable them to attain positive net income after realizing securities gains. Thus, we predict that they smooth earnings, i.e., that $\beta_{1}$ is negative.

\footnotetext{
${ }^{15} \mathrm{We}$ do not include NIpos $\times \mathrm{UG}_{\mathrm{t}-1}$ and RegCapLow $\times \mathrm{UL}_{\mathrm{t}-1}$ in Eq. (2) because we have no predictions for the signs of their coefficients. Untabulated findings reveal that including these variables does not affect our inferences. The only difference is that the RegCapLow coefficient has the predicted sign (t-stat. =1.34).
} 
Second, we estimate Eq. (1) without the interaction terms and firm fixed effects, using banks with negative $\mathrm{NI}$ but positive net income after realized gains on AFS securities, i.e., $\mathrm{NI}<0$ and $\mathrm{NI}+\mathrm{RGL}>=0$. We exclude firm fixed effects because there are few banks in this subsample with more than one observation. Because these banks avoided a loss by realizing securities gains, $\beta_{1}$, the $\mathrm{NI}$ coefficient, is negative by construction. However, the coefficient magnitude is not determined by construction. Thus, we test whether $\beta_{1}$ equals -100 , i.e., $-100 \%$, to gauge the extent to which these banks offset negative NI with realized gains on AFS securities. We include RegCapLow with the control variables because the observations all have NI $<0$ and, thus, we have no prediction for its coefficient.

4 Sample, data, and descriptive statistics

We base our sample on commercial banks and bank holding companies in the US Federal Reserve Bank of Chicago Database, which contains quarterly accounting information from forms filed by regulated depository financial institutions. Our sample comprises all top holder banks with data required for our tests from 1996 to 2011. ${ }^{16}$ We exclude observations from Q1 2008 through Q2 2009 to avoid the potential for the financial crisis to affect our inferences; NBER business cycle dates. indicate that a recession started in December 2007 and ended in June 2009. The sample begins in 1996 when regulatory capital ratios became publicly available. ${ }^{18}$ We obtain VIX from the Federal Reserve Bank of St. Louis, Unemp from Consensus Economics' Consensus Forecasts database, and LIBOR from the International Monetary Fund. The resulting sample comprises 136,879 bank-quarter observations for 6300 banks, with 15,204 (121,675) observations for 728 (5862) publicly listed (non-listed) banks. ${ }^{17}$

Realized gains and losses on AFS securities, RGL, is reported in line $6 \mathrm{~b}$ of Schedule HI (RI) Income Statement for bank holding companies (other commercial banks). ${ }^{20}$ Accumulated unrealized gains and losses on AFS securities is the difference between total fair value and amortized cost for these securities as reported in Schedule HC-B (RC-B) Securities for bank holding companies (other commercial banks). Unrealized gains and unrealized losses are reported separately for twenty-one categories of

\footnotetext{
${ }^{16}$ All commercial banks file regulatory reports. Bank holding companies control, directly or indirectly, one or more commercial banks. A bank holding company can control another bank holding company, which controls commercial banks. The top holder is the entity that tops the control chain, which could be a commercial bank. ${ }^{18}$ ASC 320 required the classification of securities into trading, available for sale, and held to maturity beginning in 1994. Untabulated findings reveal that beginning the sample in 1994 does not affect our inferences.

${ }^{17}$ The sum of 728 and 5862 exceeds 6300 because 290 banks changed status during the sample period. ${ }^{20}$ Realized gains and losses on AFS securities, RGL, comprises gains and losses realized by sale or other disposal of the securities and losses arising from other than temporary impairment (OTTI) of the securities. The timing and amount of sales or other disposals are discretionary, and those of OTTI require application of management judgement. Thus, both can be used to manage earnings.
} 
securities. We use the by-category information to construct UG (UL), accumulated unrealized gains (losses) on AFS securities. Specifically, if the difference between fair value and amortized cost for a particular category of securities is positive (negative), we include that difference in UG (UL). ${ }^{18}$

Table 1, panel A, presents distributional statistics for variables we use in our estimating equations. Panel A reveals that, on average, banks realize gains on AFS securities (mean $R G L=0.01$ ); the median is zero. On average, net income before realized gains and losses on AFS securities, $\mathrm{NI}$, also is positive (mean $=0.27$; median $=0.31$ ). Means (medians) of negative and positive NI, NIneg and NIpos, are -0.05 and 0.32 (0.00 and 0.31), which indicate that, although average negative $\mathrm{NI}$ is $-0.05 \%$ of total assets, average positive $\mathrm{NI}$ is considerably larger in magnitude, $0.32 \%$. Untabulated statistics reveal that $\mathrm{NI}$ is positive, negative, and zero for 121,234, 15,534, and 111 observations (6120, 3341, and 100 banks). Mean (median) RegCap, regulatory capital ratio before realized gains and losses on AFS securities, which we use to construct RegCapLow, is 0.19 (0.16). Panel A also reveals that, on average,

banks' accumulated unrealized gains is $0.26 \%$ of total assets (mean UG $=0.26$ ), and accumulated unrealized losses is $0.18 \%$ (mean $\mathrm{UL}=-0.18$ ). Untabulated statistics reveal that $81 \%$ (70\%) of the observations have positive (negative) UG (UL).

Table 1, panel B, presents Pearson (Spearman) correlations above (below) the diagonal. Consistent with our predictions, panel B reveals that RGL is significantly negatively related to NI (Pearson corr. $=-0.07$; Spearman corr. $=-0.08$ ). ${ }^{19}$ Although almost all correlations are significantly different from zero, most are less than 0.25. The notable exceptions are the correlations between NI and its partitions, NIneg and Nipos, which is to be expected. Regardless, we rely on multivariate regressions to test our predictions.

\footnotetext{
${ }^{18}$ Beginning in 2009, listed banks must disclose gross unrealized gains and losses on AFS securities in Form 10-Q. Although some listed banks disclosed the amounts before this date, the disclosures are not available for non-listed banks or throughout our sample period. To assess the validity of UG and UL in capturing gross unrealized gains and losses, we hand-collected the gross amounts for 4071 bank-quarter observations for 461 banks from 2005 to 2011. Untabulated statistics reveal that the median ratio of gross unrealized gains (losses) on AFS securities to UG (UL) is 1.23 (1.18), which indicates that UG (UL) understates the gross amounts by $23 \%$ (18\%). However, untabulated findings from estimating Eq. (2) using the handcollected data when available, and UG and UL otherwise, reveal the same inferences as those revealed by the tabulated findings.

${ }^{19}$ We use the term Bsignificant ${ }^{\wedge}$ to denote statistical significance at the $5 \%$ level based on a one-sided test when we have a signed prediction and a two-sided test otherwise.
} 


\section{Findings}

5.1 Earnings smoothing and increasing regulatory capital

Table 2 presents regression summary statistics from two versions of Eq. (1) - without and with the interaction variable. Consistent with predictions and inferences from prior research, both sets of findings reveal that realized gains and losses on AFS securities, RGL, is significantly negatively related to net income before the gains and losses, $\mathrm{NI}$ (tstats. $=-3.72$ and -3.66 ), and significantly positively related to the indicator for low regulatory capital before the gains and losses, RegCapLow (t-stats. $=1.82$ and 1.71). Table 2 also reveals that the $\mathrm{NI} \times$ RegCapLow coefficient is not significantly different from zero $(\mathrm{t}$-stat. $=-0.84)$. This finding indicates that there is no interaction between the incentives to smooth earnings and manage regulatory capital or that the interaction for positive and negative NI banks offset.

Regarding the control variables, the coefficients on accumulated unrealized gains and losses on AFS securities, $\mathrm{UL}_{\mathrm{t}-1}$ and $\mathrm{UG}_{\mathrm{t}-1}$, are positive in both versions ( $\mathrm{t}$-stats. $=$ 3.72 and 3.72 for $U L_{t-1}$ and 11.23 and 11.24 for $U G_{t-1}$, which indicates that banks realize more losses (gains) when they have more accumulated unrealized losses (gains). Untabulated coefficients on several other control variables differ from zero. $^{20}$

Descriptive statistics.

\footnotetext{
${ }^{20}$ Prior research (e.g., Scholes et al. 1990) considers tax incentives for banks to realize securities gains and losses. Beatty and Harris (1998) includes in its equation analogous to Eq. (1) an indicator variable that equals one if the bank reports positive tax expense before the tax on realized securities gains, and zero otherwise. This variable is not available during our sample period. Instead, we re-estimate Eq. (1) including an alternative tax indicator variable that equals one if the bank has positive tax expense, and zero otherwise. Untabulated findings reveal that its inclusion yields inferences consistent with those we obtain from Eq. (1). The tstatistics associated with the untabulated NI, RegCapLow, and NI×RegCapLow coefficients are $-5.37,1.36$, and -0.18 .
} 
Table 1

\begin{tabular}{llll}
\hline \multicolumn{2}{l}{$\begin{array}{l}\text { Panel A: Distributional statistics } \\
\text { Mean }\end{array}$} & Median & StdDev \\
RGL & 0.01 & 0.00 & 0.03 \\
$\mathrm{NI}$ & 0.27 & 0.31 & 0.36 \\
NIneg & -0.05 & 0.00 & 0.22 \\
NIpos & 0.32 & 0.31 & 0.23
\end{tabular}




\begin{tabular}{|c|c|c|c|c|c|c|c|c|c|c|}
\hline \multicolumn{3}{|l|}{ RegCap } & \multicolumn{3}{|l|}{0.19} & \multicolumn{3}{|l|}{0.16} & \multicolumn{2}{|l|}{0.11} \\
\hline \multicolumn{3}{|l|}{ UG } & \multicolumn{3}{|l|}{0.26} & \multicolumn{3}{|l|}{0.09} & \multicolumn{2}{|l|}{0.44} \\
\hline \multicolumn{3}{|l|}{ UL } & \multicolumn{3}{|l|}{-0.18} & \multicolumn{3}{|l|}{-0.03} & \multicolumn{2}{|l|}{0.36} \\
\hline \multicolumn{3}{|l|}{ Size } & \multicolumn{3}{|l|}{12.08} & \multicolumn{3}{|l|}{12.04} & \multicolumn{2}{|l|}{1.52} \\
\hline \multicolumn{3}{|l|}{$\mathrm{Sec}$} & \multicolumn{3}{|l|}{25.74} & \multicolumn{3}{|l|}{23.08} & \multicolumn{2}{|l|}{15.45} \\
\hline \multicolumn{3}{|l|}{ Liquid } & \multicolumn{3}{|l|}{4.45} & \multicolumn{3}{|l|}{3.03} & \multicolumn{2}{|l|}{4.86} \\
\hline \multicolumn{3}{|l|}{ VIX } & \multicolumn{3}{|l|}{21.10} & \multicolumn{3}{|l|}{21.53} & \multicolumn{2}{|l|}{5.82} \\
\hline \multicolumn{3}{|l|}{ Unemp } & \multicolumn{3}{|l|}{5.79} & \multicolumn{3}{|l|}{5.14} & \multicolumn{2}{|l|}{1.63} \\
\hline \multicolumn{3}{|l|}{ LIBOR } & 0.38 & & & 0.24 & & & 0.32 & \\
\hline $\begin{array}{l}\text { Panel B: } \\
\text { Matrix }\end{array}$ & Correl & tion & & & & & & & & \\
\hline & RGL & $\mathrm{NI}$ & NIneg & NIpos & RegCap & UG & UL & Size & $\mathrm{Sec}$ & Liquid \\
\hline RGL & & -0.07 & -0.02 & -0.07 & -0.06 & 0.25 & 0.11 & 0.17 & 0.07 & -0.09 \\
\hline $\mathrm{NI}$ & -0.08 & & 0.55 & 0.99 & 0.03 & 0.03 & 0.01 & 0.13 & 0.06 & -0.16 \\
\hline NIneg & -0.03 & 0.80 & & 0.55 & -0.01 & 0.07 & -0.03 & 0.12 & 0.10 & -0.15 \\
\hline Nlpos & -0.09 & 0.82 & 0.32 & & 0.03 & 0.03 & 0.01 & 0.13 & 0.06 & -0.16 \\
\hline RegCap & -0.01 & 0.03 & -0.08 & 0.11 & & 0.08 & -0.03 & -0.43 & 0.50 & 0.27 \\
\hline UG & 0.21 & 0.04 & 0.05 & 0.02 & 0.16 & & 0.44 & 0.19 & 0.24 & -0.09 \\
\hline UL & 0.11 & -0.00 & -0.02 & 0.02 & -0.12 & 0.13 & & 0.01 & -0.19 & 0.06 \\
\hline Size & 0.06 & 0.11 & 0.06 & 0.12 & -0.35 & 0.07 & 0.10 & & -0.16 & -0.52 \\
\hline $\mathrm{Sec}$ & 0.06 & 0.08 & 0.07 & 0.06 & 0.52 & 0.25 & -0.26 & -0.16 & & 0.01 \\
\hline Liquid & -0.01 & -0.16 & -0.13 & -0.13 & 0.20 & -0.04 & 0.03 & -0.33 & -0.06 & \\
\hline
\end{tabular}

Table 18 
RGL is realized gains and losses on available for sale (AFS) securities, deflated by beginning-of-quarter total assets. $\mathrm{NI}$ is net income before taxes and RGL, deflated by beginning-of-quarter total assets. NIneg (NIpos) is $\mathrm{NI}$ when $\mathrm{NI}$ is less than (greater that or equal to) zero, and zero otherwise. RegCap is the bank's regulatory capital ratio, which is allowable Tier 1 plus allowable Tier 2 regulatory capital before RGL and after taxes, deflated by risk-weighted assets. UG (UL) is accumulated unrealized AFS securities gains (losses), deflated by beginning-of-quarter total assets. Size is the natural logarithm of beginning-of-quarter total assets. Sec is the sum of held-to-maturity, available-for-sale, and trading securities. Liquid is total liquid assets, deflated by beginning-of-quarter total assets. VIX is implied volatility of options on the S\&P 500 Index. Unemp is the oneyear-ahead consensus forecast of the US unemployment rate. LIBOR is the difference between the London Interbank Offer Rate and overnight indexed swap rates.

Sample comprises 136,879 bank-quarter observations for 6300 banks, over the period from Q1 1996 to Q4 2007 and from Q3 2009 to Q4 2011.

In panel A, all distributional statistics, except for RegCap, Size, VIX, Unemp, and LIBOR, are multiplied by 100 for expositional convenience.

In panel B, Spearman (Pearson) correlation coefficients are shown above (below) the diagonal. Panel B excludes VIX, Unemp, and LIBOR because they are year-specific variables. All correlations are significant at the 0.01 level except when marked with ${ }^{\dagger}$.

Summary statistics from regressions of realized AFS securities gains and losses, RGL, on proxies for incentives to manage reported earnings and regulatory capital

\begin{tabular}{|c|c|c|c|c|c|}
\hline & & Model I & & Model II & \\
\hline Variables & Prediction & Coeff. & t-stat. & Coeff. & t-stat. \\
\hline \multicolumn{6}{|l|}{$\begin{array}{l}\text { Experimental } \\
\text { variables: }\end{array}$} \\
\hline $\mathrm{NI}$ & - & $-0.45^{* * *}$ & -3.72 & $-0.42 * * *$ & -3.66 \\
\hline RegCapLow & + & $0.01 *$ & 1.82 & $0.01 *$ & 1.71 \\
\hline NI×RegCapLow & $-1+$ & & & -0.10 & -0.84 \\
\hline \multicolumn{6}{|l|}{ Control variables: } \\
\hline ULt-1 & & 1.12 & 3.72 & 1.12 & 3.72 \\
\hline UGt-1 & & 1.35 & 11.23 & 1.35 & 11.24 \\
\hline Other controls & & Yes & & Yes & \\
\hline Bank fixed effects & & Yes & & Yes & \\
\hline $\operatorname{Adj} . R^{2}$ & & $5.4 \%$ & & $5.4 \%$ & \\
\hline
\end{tabular}

See Table 1 for variable definitions. Other controls comprises Size, Sec, Liquid, VIX, Unemp, and LIBOR. Regressions include bank fixed effects.

t-statistics are based on standard errors clustered by bank and quarter. Coefficient estimates are multiplied by 100 for expositional convenience. Estimations are based on 136,879 bank-quarter observations (6300 banks) over the period from Q1 1996 to Q4 2007 and from Q3 2009 to Q4 2011. 
Table 20

$*, * *$, and $* * *$ denotesignificanceof experimental variables (based on two-tail tests) at $0.10,0.05$, and 0.01 levels.

5.2 Big baths and the opportunity for managing earnings and regulatory capital

Table 3 presents summary statistics from estimating three versions of Eq. (2). The first two are analogous to those in Table 2 but separate positive and negative $\mathrm{NI}$ observations, and the third adds the opportunity interaction variables. Table 3 reveals, as predicted, that in all three versions the NIneg coefficients are positive, and significantly so in the second and third (t-stats. $=1.61,3.50$, and 4.12 ), which indicates that banks with more negative earnings realize more losses or fewer gains on AFS securities. That is, they take a big bath. Table 3 also reveals that the NIpos coefficients are significantly negative in all three versions (t-stats. $=-6.94,-7.04$, and -7.08), which indicates that banks with more positive earnings realize fewer gains or more losses on AFS securities. That is, they smooth earnings. Together, these findings reveal that the evidence of earnings smoothing in Table 2 and prior research is a net result dominated by banks with positive earnings. Banks with negative earnings take a big bath; they do not smooth earnings.

Table 3 also reveals that the insignificant interaction between the incentives to manage earnings and regulatory capital in Table 2 is attributable to not distinguishing between positive and negative NI banks. In particular, in Models II and III the NIneg $\times$ RegCapLow coefficients are significantly negative (t-stats. $=-4.00$ and -4.17 ), which indicates that negative $\mathrm{NI}$ banks with low regulatory capital engage in significantly less big bath earnings management. In Model II the total coefficient of $-0.21,0.43-0.64$, is not significantly different from zero (t-stat. $=-1.07$ ), which indicates that low regulatory capital eliminates the incentive for negative NI banks to 


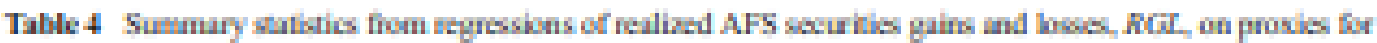

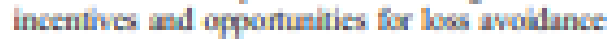

\begin{tabular}{|c|c|c|c|c|c|c|c|}
\hline \multirow[b]{2}{*}{ Varblas } & \multirow[b]{2}{*}{ Prudikting } & \multicolumn{2}{|l|}{$N J=0$} & \multicolumn{2}{|c|}{$M<0$ and $N F+C G<0$} & \multicolumn{2}{|c|}{$\begin{array}{c}M-0 \text { and } M+ \\
L G=0\end{array}$} \\
\hline & & CwI. & E-hat. & Cuft & ithial. & Curl. & I-stal. \\
\hline \multicolumn{8}{|c|}{ Espranenul valdis: } \\
\hline Norts & $+1-$ & & & 1049:14 & $2 . \mathrm{s}$ & 0.10 & 0.25 \\
\hline Mrwas & - & $-1.33+17$ & -7.41 & & & & \\
\hline \multicolumn{8}{|l|}{ Conmel nutbls: } \\
\hline Rintapim & & 001 & 1.42 & 001 & $\mathbb{1 . P}$ & a.t & I.1.5 \\
\hline$\left[Z_{1-1}\right.$ & & 094 & 438 & 1.49 & $2 \omega$ & 4.07 & 4.5 \\
\hline$\left[\bar{T}_{1-1}\right.$ & & 121 & 11.65 & 871 & S.RS & 3.04 & 5.9 \\
\hline Dhts subuls & & $\mathrm{Yes}$ & & $\mathrm{Mel}$ & & res & \\
\hline Band foud afins & & $\mathrm{Ys}$ & & Yei & & rs & \\
\hline $\mathbf{N}$ & & 121,345 & & 11,312 & & 4272 & \\
\hline Ay. $\mathrm{R}^{2}$ & & $53 \%$ & & 745 & & $6+7$ & \\
\hline
\end{tabular}

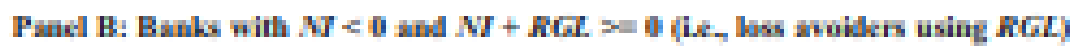

\begin{tabular}{|c|c|c|c|c|c|}
\hline \multirow[b]{2}{*}{ Varbbas } & \multicolumn{3}{|c|}{ Mode I } & \multicolumn{2}{|l|}{ Madst II } \\
\hline & Frudictiun & Cadt & intat. & Cacit. & Mbit. \\
\hline \multicolumn{6}{|c|}{ Eqperimenul vaibles: } \\
\hline Nhes & - & $-9633=12$ & -35.09 & $-34.15=4$ & -36.78 \\
\hline \multicolumn{6}{|l|}{ Connd buthls: } \\
\hline Putcalim & & & & -0.01 & -0.54 \\
\hline $\mathrm{CZ}_{\Perp-\mathrm{i}}$ & & & & 023 & 037 \\
\hline $\operatorname{LG}_{\mathrm{I}-\mathrm{i}}$ & & & & 25 & 6.05 \\
\hline This crintrob & & \multicolumn{2}{|l|}{ Wu } & \multicolumn{2}{|l|}{$\mathrm{Hes}$} \\
\hline $\mathrm{N}$ & & \multicolumn{2}{|l|}{917} & \multicolumn{2}{|l|}{917} \\
\hline Ay.R & & \multicolumn{2}{|l|}{41.75} & \multicolumn{2}{|l|}{$4 \mathrm{R} 3 \mathrm{~h}$} \\
\hline TES $100 . \bar{m}_{1}<-100$ & & \multicolumn{2}{|c|}{ l-subtis $=1.45$} & \multicolumn{2}{|c|}{ Matalk = 692 } \\
\hline
\end{tabular}

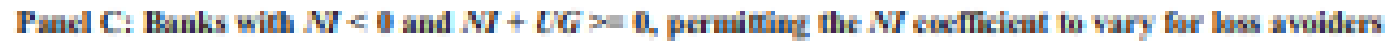
Varblas Frullition Cuet. I-ibet

Experimenul viribles:

\begin{tabular}{|c|c|c|c|}
\hline Nots & - & $-6.13^{414}$ & -897 \\
\hline Lws_woldt & 4 & $0.00+17$ & 16.86 \\
\hline 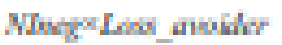 & - & $-7 \times 29=1$ & -19.48 \\
\hline
\end{tabular}

Connd mitules.

\begin{tabular}{|c|c|}
\hline Fing Carkm & 0.1 \\
\hline $\mathrm{LI}_{\mathbf{M}-\mathrm{i}}$ & 3.59 \\
\hline$\left[\bar{G}_{\mathbf{I}-1}\right.$ & 154 \\
\hline Mhe matruls & $\mathrm{Yes}$ \\
\hline Bund fene afing & Yes \\
\hline
\end{tabular}


Table 4 (continued)

\begin{tabular}{ll}
\hline $\mathrm{N}$ & 4,222 \\
Adj. $\mathrm{R}^{2}$ & $40.0 \%$ \\
\hline
\end{tabular}

See Table 1 for variable definitions. Other controls comprises Size, Sec, Liquid, VIX, Unemp, and LIBOR. Regressions include bank fixed effects.

t-statistics are based on standard errors clustered by bank and quarter. Coefficient estimates, except for the interactions of NIneg and NIpos with UL and UG, are multiplied by 100 for expositional convenience. Estimations are based on 136,879 bank-quarter observations (6300 banks) over the period from Q1 1996 to Q4 2007 and from Q3 2009 to Q4 2011.

$*$, **, and $* * *$ denotesignificanceof experimental variables (based on two-tail tests) at $0.10,0.05$, and 0.01 levels.

engage in big bath earnings management. Conditional on NIneg $\times$ RegCapLow, the RegCapLow coefficient is not significantly different from zero ( $\mathrm{t}$-stat. $=1.43$ ).

Regarding the opportunity to manage earnings and regulatory capital, in Model III the NIneg $\times U L_{t-1}$ coefficient is significantly negative ( $\mathrm{t}$-stat. $=-3.62$ ), which indicates that banks with more negative earnings and larger accumulated unrealized losses engage in more big bath earnings management. The NIneg $\times \mathrm{UG}_{\mathrm{t}-1}$ coefficient is significantly negative ( $\mathrm{t}$-stat. $=-4.38$ ), which indicates that banks with more negative earnings realize more net gains on AFS securities when they have more accumulated unrealized gains. That is, they engage in more earnings smoothing. The NIpos $\times U_{L_{t-1}}$ coefficient is significantly negative ( $\mathrm{t}$-stat. $\left.=-3.19\right)$, which is not consistent with our prediction. ${ }^{21}$ The RegCapLow $\times U_{G_{t-1}}$ coefficient is significantly positive (t-stat. $=4.46)$, as predicted, which indicates that banks with low regulatory capital realize.

Table 22

more securities gains when they have more accumulated unrealized gains. However, after inclusion of NIneg $\times$ RegCapLow and RegCapLow $\times U G_{t-1}$, the RegCapLow

\footnotetext{
${ }^{21}$ Section 5.5.3 reports findings from additional analyses that indicate this unpredicted sign is attributable to assuming all NIpos banks have the same incentives for earnings management, namely to smooth earnings, whereas some might have earnings management benchmarks other than zero earnings.
} 
coefficient is significantly negative, not positive ( $\mathrm{t}$-stat. $=-2.00$ ). Taken together, these findings reveal that banks engage in more earnings management-either big bath or smoothing - and more regulatory capital management when they have more opportunity to do so. ${ }^{22}$

The sample underlying the tabulated findings excludes observations from the financial crisis. Untabulated findings reveal that including crisis observations affects the inferences we obtain from estimating Eq. (1). In particular, the untabulated NI, RegCapLow, and $\mathrm{NI} \times$ RegCapLow coefficients based on Model II in Table 2 are insignificantly different from zero, significantly positive, and significantly negative (t-stats. $=-0.13,1.96$, and -2.29), whereas they are significantly negative, significantly positive, and insignificantly different from zero in Table 2 . However, including these observations does not affect the inferences we obtain from estimating Eq. (2), except that the RegCapLow coefficient does not have an unpredicted sign ( $t$ stat. $=0.11$ ). These untabulated findings reveal that permitting coefficients to differ for positive and negative NI, and UG and UL, is particularly important during the crisis.

\subsection{Avoiding losses}

Table 4, panel A, presents findings relating to banks' ability to avoid a loss by realizing gains on AFS securities. Panel A presents summary statistics from Eq. (2) without the interaction variables for banks with: (i) $\mathrm{NI}>=0$, (ii) $\mathrm{NI}<0$ and $\mathrm{NI}+\mathrm{UG}$ $<0$, and (iii) $\mathrm{NI}<0$ and $\mathrm{NI}+\mathrm{UG}>=0$. The findings for banks with $\mathrm{NI}>=0$ confirm the Table 3 finding that banks with positive NI smooth earnings with realized securities gains and losses; the NIpos coefficient is significantly negative (t-stat. $=$ -7.41). In contrast, for banks with $\mathrm{NI}<0$ and $\mathrm{NI}+\mathrm{UG}<0$ the NIneg coefficient is significantly positive ( $\mathrm{t}$-stat. $=2.96)$, which indicates that banks with negative $\mathrm{NI}$ take a big bath when it is not feasible to report positive net income by realizing gains on AFS securities. This finding does not apply to banks with $\mathrm{NI}<0$ and $\mathrm{NI}+\mathrm{UG}>=0$,

\footnotetext{
${ }^{22}$ As footnote 4 explains, $45 \%$ of unrealized gains and losses on equity AFS securities affect regulatory capital. Although this reduces banks' ability to affect regulatory capital by realizing gains and losses on AFS securities, equity securities comprise a small proportion of AFS securities for our sample. Nonetheless, we reestimated the five specifications of Eqs. (1) and (2) in Tables 2 and 3 including an indicator variable, Q5, which equals one if the bank's ratio of AFS equity securities to total AFS securities is in the highest quintile across banks in quarter $t$ and zero otherwise, and Q5 interacted with RegCapLow, RegCapLow $\times$ Q5. Consistent with banks with low regulatory capital and more AFS equity securities realizing fewer gains, but also with the estimations lacking power, untabulated statistics reveal that the RegCapLow $\times$ Q 5 coefficients are negative, but not significantly so, in all five specifications (t-statistics range from -0.71 to -1.51 ). The untabulated statistics reveal the same inferences regarding RegCapLow as those based on Tables 2 and 3; the t-statistics are 1.96 and 1.88 in the Table 2 specifications and 2.51, 1.48, and -1.66 in the Table 3 specifications.
} 
i.e., banks that have sufficient unrealized gains to avoid a loss. For these banks, there is no significant relation between NIneg and RGL (t-stat. $=0.25$ ).

Table 4, panel B, presents summary statistics relating to banks that realized gains on AFS securities to avoid a loss, i.e., banks with negative $\mathrm{NI}$ but $\mathrm{NI}+\mathrm{RGL}>=0$. Panel B presents findings based on an equation with NIneg as the only explanatory variable, Model I, and based on Eq. (2) without the interaction terms, Model II. As expected by construction, panel B reveals that the NIneg coefficient is significantly negative in both specifications (t-stats. $=-38.03$ and -36.78 ). However, panel B also reveals that in Model I the NIneg coefficient is -96.33 , which is not significantly different from -100 ( $\mathrm{t}$-stat. $=1.45)$. This finding is not by construction and indicates that these banks realized just enough gains on AFS securities to turn negative $\mathrm{NI}$ into positive net income, even though untabulated statistics reveal that mean UG for these banks is more than eight times mean NI, 0.43 versus -0.05 . In Model II, the NIneg coefficient is smaller, -84.15 versus -96.33 , which indicates NIneg is correlated with the control variables.

Untabulated statistics reveal that 818 of the 917 panel B observations have not only $\mathrm{NI}<0$ and $\mathrm{NI}+\mathrm{RGL}>0$, but also $\mathrm{NI}+\mathrm{UG}>=0$, and are included in panel A, Model III. Thus, to provide insights into whether the presence of loss avoiders masks the relation between RGL and NIneg, we re-estimate the specification in panel A permitting the NIneg coefficient to vary for banks that avoided a loss by realizing securities gains. Panel C presents the results. The NIneg coefficient is significantly negative for banks that did not avoid a loss using realized gains (coef. $=-6.13$; t-stat. $=-8.97$ ), which is consistent with earningssmoothing. As expected based on panel $\mathrm{B}$, the NIneg coefficientfor loss avoiders is even more negative (incremental coef. $=$ -78.29 ; t-stat. $=-19.48$ ); the total NIneg coefficient for loss avoiders of -84.42 , i.e., $-6.13-78.29$, is close to the -84.15 coefficient in panel $\mathrm{B}$, which is essentially a $100 \%$ offset. Panel C also reveals that loss avoiders have significantly higher RGL (incremental intercept $=0.05$; t-stat. $=16.86$ ), which likely explains the insignificant NIneg coefficient in panel A. ${ }^{23}$

5.4 Listed versus non-listed banks

\footnotetext{
${ }^{23}$ Untabulated findings based on a specification that permits all coefficients to differ for loss avoiders reveal the same inferences as the findings in panel C.
} 
As noted in section 2.2, Beatty and Harris (1998) finds that both listed and non-listed banks engage in earnings smoothing using realized securities gains and losses, but that listed banks do so to a greater extent. Thus, we estimate Eqs. (1) and (2) separately for listed and non-listed banks and test whether they differ in the extent to which, and how, they manage earnings and regulatory capital. We tabulate these separate estimations to facilitate comparison of coefficients, but test for coefficient equality by pooling observations and permitting the coefficients to differ for listed and non-listed banks.

Table 5 presents regression summary statistics from Eq. (1), in panel A, and Eq. (2), in panel B, separately for listed and non-listed banks. Panel A reveals inferences for both types of banks consistent with those revealed by Table 2. The only exception is that there is no evidence that non-listed banks with low regulatory capital realize more net securities gains. However, untabulatedstatisticspermitting allcoefficientsto vary for listedand nonlisted banks reveal no differences in the $\mathrm{NI}$ and RegCapLow coefficients for the two types of banks. The untabulated t-statistics relating to Models I and II are -0.55 and -0.82 (1.37 and 0.76) for the NI (RegCapLow) coefficients for listed banks, and there is no difference for the $\mathrm{NI} \times$ RegCapLow coefficient in Model II (t-stat. $=0.59){ }^{24}$

Regarding Eq. (2), panel B reveals the same inferences as Table 3 for both types of banks, with the following exceptions: In Model I, the NIneg coefficient is significantly

Table 4 Summary statistics from regressions of realized AFS securities gains and losses, RGL, on proxies for incentives and opportunities for loss avoidance

Panel A: Subsamples based on incentives and opportunity to use RGL for loss avoidance

\footnotetext{
${ }^{24}$ Untabulated statistics from estimations of the two versions of Eq. (1) but permitting only the NI, RegCapLow, and NI×RegCapLow coefficients to vary for listed banks reveal inferences identical to those from the estimation that permits all coefficients to vary. The t-statistics are 0.26 and 0.10 (1.30 and 0.86) for the incremental NI (RegCapLow) coefficients for listed banks; the t-statistic for the incremental NI×RegCapLow coefficient is 0.30 .
} 


$$
\begin{array}{ll}
\mathrm{NI}>=0 & \mathrm{NI}<0 \text { and } \mathrm{NI}+\mathrm{UG} \mathrm{NI}<0 \text { and } \\
& \mathrm{NI}+\mathrm{UG} \\
& >=0
\end{array}
$$

Variables PredictionCoeff. t-stat. Coeff. t-stat. Coeff. t-

Experimental

stat.

variables:

\begin{tabular}{|c|c|c|c|c|c|}
\hline RegCapLow & 0.01 & 1.42 & 0.01 & 1.09 & 0.01 \\
\hline ULt-1 & 0.94 & 4.38 & 1.49 & 2.80 & 4.07 \\
\hline UGt-1 & 1.21 & 11.08 & 8.71 & 5.85 & 3.04 \\
\hline Other controls & Yes & & Yes & & Yes \\
\hline $\begin{array}{l}\text { Bank fixed } \\
\text { effects }\end{array}$ & Yes & & Yes & & Yes \\
\hline N & 121,345 & & 11,312 & & 4222 \\
\hline Adj. $R^{2}$ & $5.3 \%$ & & $7.4 \%$ & & $6.4 \%$ \\
\hline
\end{tabular}

$\begin{array}{lllll}\text { NIneg } & +/- & 0.49 * * * 2.96 & 0.20 & 0.25 \\ \text { NIpos } & - & -1.33 * * *-7.41 & & \end{array}$

Control variables:

\begin{tabular}{|c|c|c|c|}
\hline & Model I & Model II & \\
\hline Variables & PredictionCoeff. t-stat. & Coeff. & t-stat. \\
\hline \multicolumn{4}{|l|}{$\begin{array}{l}\text { Experimental } \\
\text { variables: }\end{array}$} \\
\hline NIneg & $-96.33 * * *-38.03$ & $-84.15 * * *$ & -36.78 \\
\hline \multicolumn{4}{|l|}{ Control variables: } \\
\hline RegCapLow & & -0.01 & -0.54 \\
\hline ULt-1 & & 0.23 & 0.37 \\
\hline UGt-1 & & 2.95 & 6.05 \\
\hline Other controls & No & Yes & \\
\hline
\end{tabular}

Panel B: Banks $<0$ and $\mathrm{NI}+\mathrm{RGL}>=0$ (i.e., loss avoiders with $\mathrm{NI} \quad$ using RGL) 


\begin{tabular}{|c|c|c|}
\hline $\mathrm{N}$ & 917 & 917 \\
\hline Adj. $R^{2}$ & $41.7 \%$ & $48.3 \%$ \\
\hline $\begin{array}{l}\text { Test: H0: } \alpha_{1}< \\
-100\end{array}$ & t-statistic $=1.45$ & t-statistic $=6.92$ \\
\hline Panel C: Banks with NI & $\mathrm{VI}<0$ and $\mathrm{NI}+\mathrm{UG}>=($ & 0 , permitting the $\mathrm{NI}$ coefficient to vary for loss avoiders \\
\hline Variables & Prediction Coeff. & t-stat. \\
\hline \multicolumn{3}{|l|}{$\begin{array}{l}\text { Experimental } \\
\text { variables: }\end{array}$} \\
\hline NIneg & $-6.13 * * *$ & -8.97 \\
\hline Loss_avoider & $0.05^{* * *}$ & 16.86 \\
\hline NIneg×Loss_avoider & $-78.29 * * *_{-}$ & -19.48 \\
\hline \multicolumn{3}{|l|}{ Control variables: } \\
\hline RegCapLow & 0.01 & 1.07 \\
\hline ULt-1 & 3.59 & 4.11 \\
\hline UGt-1 & 1.54 & 4.35 \\
\hline Other controls & Yes & \\
\hline Bank fixed effects & Yes & \\
\hline
\end{tabular}

Table 4 (continued)

\begin{tabular}{ll}
\hline $\mathrm{N}$ & 4,222 \\
Adj.R & \\
& $40.0 \%$ \\
\hline
\end{tabular}

In panel Awe estimate the model for observations with (i) $\mathrm{NI}>=0$, (ii) $\mathrm{NI}<0$ and $\mathrm{NI}+\mathrm{UG}<0$, and (iii) $\mathrm{NI}<0$ and $\mathrm{NI}+\mathrm{UG}>=0$. Because banks in group (i) have positive $\mathrm{NI}$, we predict that they smooth earnings, i.e., we predict the NIpos coefficient is negative. Banks in group (ii) have negative NI and insufficient UG to enable them to attain positive net income after realizing securities gains. Thus, we predict that they take a big bath, i.e., we predict the NIneg coefficient is positive. Banks in group (iii) also have negative NI but have sufficient UG to enable them to attain positive net income after realizing securities gains. Thus, we predict that they smooth earnings, i.e., we predict the NIneg coefficient is negative.

In panel B we estimate our primary equation, without the interaction terms or bank fixed effects, for banks with negative $\mathrm{NI}$ but positive net income after realized gains on AFS securities, i.e., banks with $\mathrm{NI}<0$ and $\mathrm{NI}+\mathrm{RGL}>=0$. Because these banks avoided a loss by realizing securities gains, we expect that the $\mathrm{NI}$ coefficient is negative by construction. However, we test whether the NI coefficient equals -100 , i.e., $-100 \%$, to gauge the extent to which banks offset negative NI with realized gains on AFS securities.

In panel $\mathrm{C}$ we re-estimate the specification in panel A for the 4222 banks with $\mathrm{NI}<0$ and $\mathrm{NI}+\mathrm{UG}>=0$, permitting the NIneg coefficient to vary for the loss avoiders. Loss_avoider is an indicator that equals one for banks with $\mathrm{NI}<0$ and $\mathrm{NI}+\mathrm{RGL}>=0$, and zero otherwise. 
See Table 1 for other variable definitions. Other controls comprises Size, Sec, Liquid, VIX, Unemp, and LIBOR. Regressions in panels $\mathrm{A}$ and $\mathrm{C}$ include bank fixed effects.

t-statistics are based on standard errors clustered by bank and quarter. Coefficient estimates are multiplied by 100 for expositional convenience. Estimations are estimated over the period from Q1 1996 to Q4 2007 and from Q3 2009 to Q4 2011.

$*$, **, and $* * *$ denotesignificanceof experimental variables (based on two-tail tests) at $0.10,0.05$, and 0.01 levels.

positive for listed banks (t-stat. $=3.13$ ), and the RegCapLow coefficient is not significantly different from zero for non-listed banks (t-stat. $=1.60)$. In Model II, the RegCapLow coefficient is significantly positive for listed banks (t-stat. $=1.93)$. In Model III, the RegCapLow coefficient is significantly positive (t-stat. =1.98), and the RegCapLow $\times U_{\mathrm{t}_{-1}}$ coefficient is not significantly different from zero $(\mathrm{t}$-stat. $=$ -0.31), for listed banks. The Model III differences indicate that unlike non-listed banks, listed banks with low regulatory capital realize more net securities gains, but the amount realized is unrelated to accumulated unrealized gains.

Untabulated statistics based on permitting all coefficients in Eq. (2) to vary for listed and non-listed banks reveal some differences between the two types of banks. Specifically, the NIpos coefficient is significantly more negative, (t-stats. range from -5.04 to -6.43 ), and the NIneg coefficient is significantly more positive (t-stats. range from 1.85 to 3.80 ), for listed banks in all three models. These findings indicate that listed banks with positive (negative) earnings smooth earnings (take a big bath) to a greater extent than non-listed banks. There is only one significant difference between listed and nonlisted banks in the extent to which they manage regulatory capitalbased on Model III, listed banks with low regulatory capital realize more net securities gains $(\mathrm{t}$-stat. $=2.75)$. The other RegCapLow and NIneg $\times$ RegCapLow coefficients generally are not significantly different (t-stats. $=1.86$ and $0.99 ;-0.63$ and -1.09 for the RegCapLow; NIneg $\times$ RegCapLow coefficients). ${ }^{25}$

\footnotetext{
${ }^{25}$ Untabulated statistics from estimations permitting only the NIneg, NIpos, RegCapLow, and NI×RegCapLow coefficients to vary for listed banks reveal the same inferences as the estimation that permits all coefficients to vary.
} 


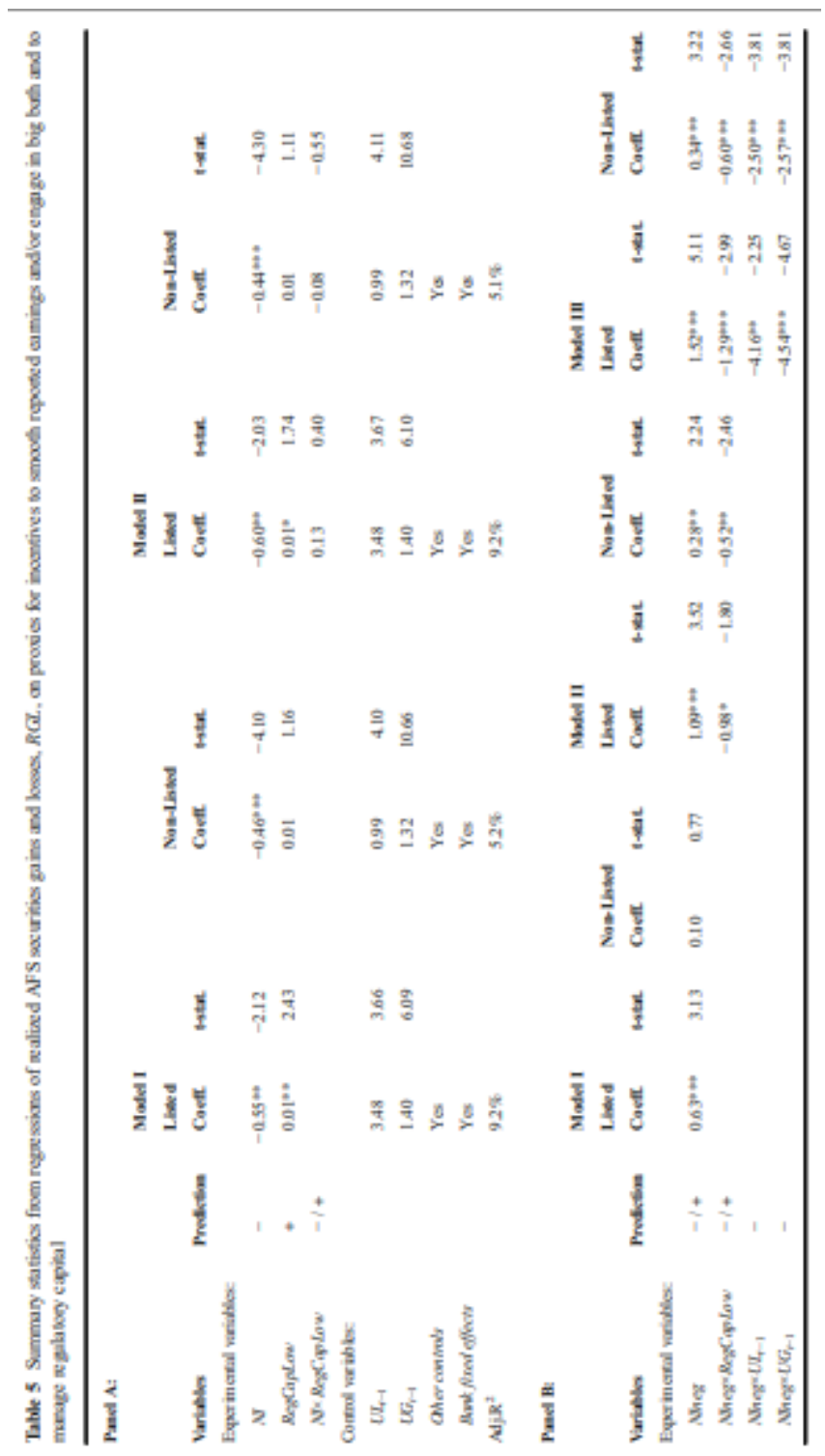




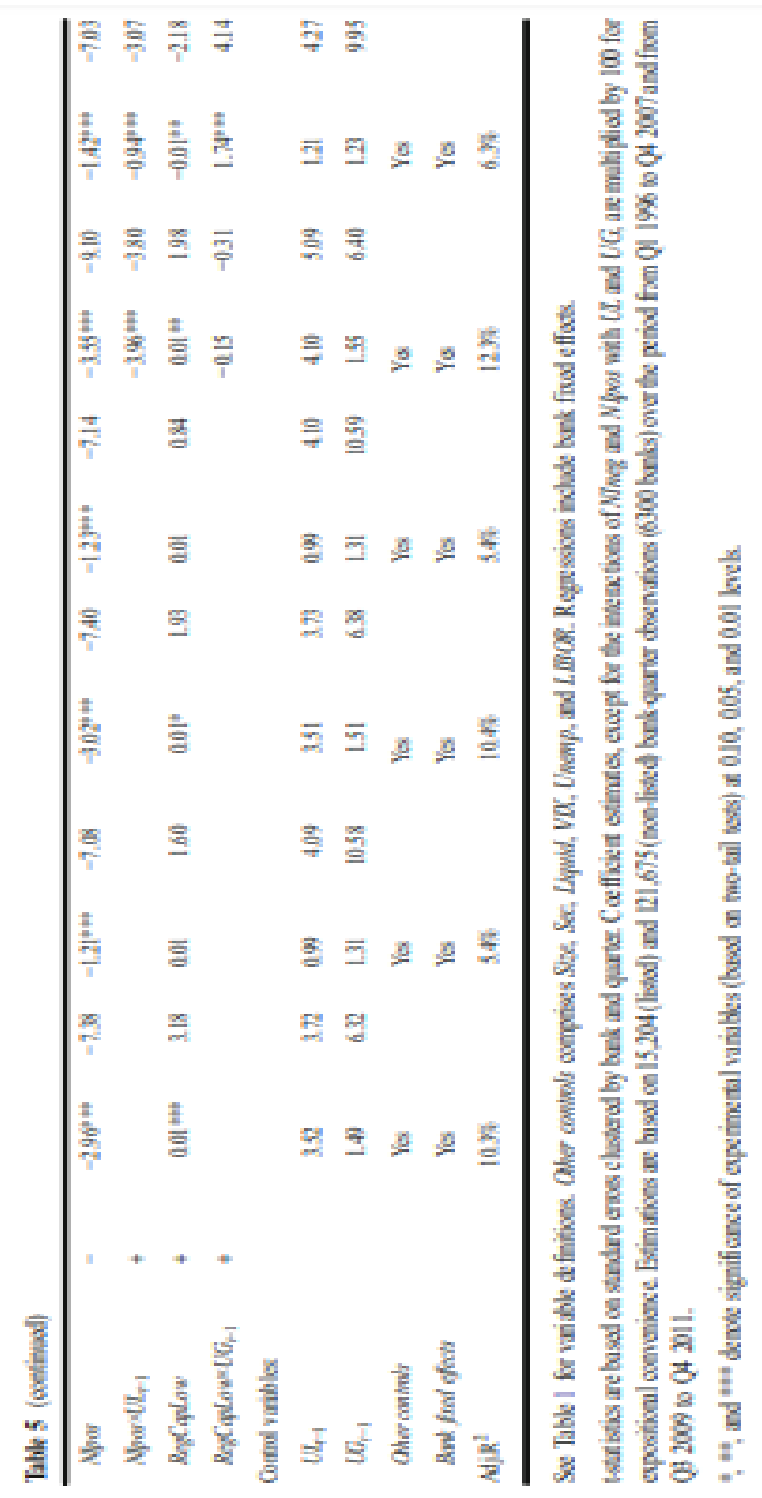


For the sake of parsimony, we do not tabulate findings from the loss avoider analyses in Table 4 separately for listed and non-listed banks. However, untabulated findings for both types of banks reveal inferences identical to those revealed by the findings in Table 4.

\subsection{Additional analyses}

5.5.1 Simultaneous use of additional earnings and regulatory capital management tools

Prior research, discussed in section 2.2, finds that banks manage earnings and regulatory capital using the loan loss provision and manage earnings using securitization gains. Changes in equity financing also can be used as a direct means to manage regulatory capital. Thus, following Beatty et al. (1995), we next test whether the simultaneous consideration of these earnings and regulatory capital management tools affects our inferences regarding realized gains and losses on AFS securities.

We use two-stage least squares to estimate systems of equations based on Eq. (1). ${ }^{26}$

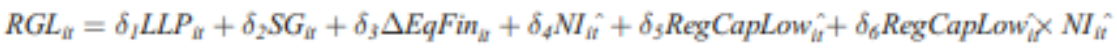

$$
\begin{aligned}
& +\delta_{7} U L_{i l-l}+\delta_{s} U G_{i l-l}+\delta_{9} \operatorname{Sec}_{i t}+\sum_{k-10}^{14} \delta_{k} \text { Common Controls }_{i t}+\varepsilon_{i t}
\end{aligned}
$$

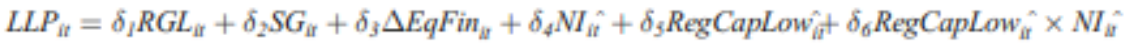

$$
\begin{aligned}
& +\delta_{7} \Delta N P L_{i t}+\delta_{\delta} L L P_{i j-I}+\delta_{9} \operatorname{Sec}_{i f}+\sum_{k-10}^{14} \delta_{k} \text { Conmon Controls }_{i t}+\varepsilon_{i t}
\end{aligned}
$$

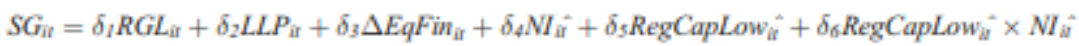

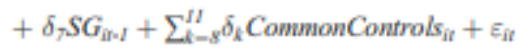

$$
\begin{aligned}
& \Delta \text { EqFin }_{i t}=\delta_{l} R G L_{\text {if }}+\delta_{2} L L P_{i t}+\delta_{j} S G_{i l}+\delta_{4} \operatorname{Reg}_{\text {CapLow }} \hat{u}^{*} \\
& +\delta_{5} \Delta \text { EqFin }_{i b-l}+\delta_{6} \text { Lev }_{i t-l}+\sum_{k-7}^{I l} \delta_{k} \text { Common Controls }_{i l}+\varepsilon_{i l}
\end{aligned}
$$

LLP is the loan loss provision, which we code as a positive number, and SG is securitization gains. $\Delta$ EqFin is change in equity other than that associated with current.

quarter comprehensive income, i.e., the change in total equity minus total comprehensive income. $\mathrm{NI}^{\wedge}$ (RegCapLow ${ }^{\wedge}$ ) is net income (regulatory capital) before RGL, LLP, and SG, and CommonControls comprises Size, Liquid, VIX, Unemp, and

\footnotetext{
${ }^{26}$ In the first stage, we estimate versions of Eqs. (3a) through (3d) that include all of the explanatory variables in the system, except for RGL, LLP, SG, and $\Delta$ EqFin. In the second stage, we estimate Eqs. (3a) through (3d) replacing RGL, LLP, SG, and $\Delta$ EqFin as explanatory variables with their predicted amounts from the first stage.
} 
LIBOR. We have no predictions for $\delta_{1}, \delta_{2}$, and $\delta_{3}$ because we have no predictions for which earnings management tools banks use, or in which order, but our predictions for the other coefficients in Eq. (3a) are the same as for Eq. (1).

To identify the system, each equation includes variables omitted from the others. Equation (3a) includes $U L_{t-1}$ and $U_{\mathrm{t}_{-1}}$ because we expect beginning-ofquarter accumulated unrecognized gains and losses on AFS securities to be associated with realized gains and losses on the securities during the quarter. Equation (3b) includes $\mathrm{LLP}_{\mathrm{t}-1}$ and $\triangle \mathrm{NPL}$, the change in nonperforming loans and leases deflated by beginning-of-quarter total assets, because we expect the bank's prior quarter loan loss provision and the change in nonperforming loans to be associated with the loan loss provision (Beatty et al. 1995). Equations (3a) and (3b) include Sec because it captures the bank's asset composition; banks with higher investment in securities tend to have lower investment in loans. Equation (3c) (Eq. (3d)) includes $S_{t-1}$ $\left(\Delta\right.$ EqFin $_{\mathrm{t}-1}$ and $\left.\mathrm{LeV}_{\mathrm{t}-1}\right)$ because we expect the bank's prior quarter securitization gains (equity financing and leverage) to be associated with the current quarter's securitization gains (equity financing).

Table 6, panel A, presents findings relating to the second-stage estimates for Eqs. (3a) through (3d). The first set of columns reveals that of the alternative dependent variables, securitization gains, SG, and change in equity financing, $\Delta$ EqFin, are significantly positively related to realized AFS securities gains and losses, RGL (tstats. $=1.74$ and 5.11). More importantly for our research question, panel A reveals that in the RGL equation, the $\mathrm{NI}^{\wedge}$ and RegCapLow ${ }^{\wedge}$ coefficients are significantly negative and positive, which is consistent with Table 2 (t-stats. $=-5.12$ and 3.26). The $\mathrm{NI}^{\wedge} \times$ RegCapLow${ }^{\wedge}$ coefficient is significantly negative (t-stat. $\left.=-2.50\right)$, whereas it is negative but insignificantly different from zero in Table $2(\mathrm{t}-\mathrm{stat} .=-0.84)$.

Panel B of Table 6 presents summary statistics from Eqs. (3a) through (3d), separating positive and negative $\mathrm{NI}$ as in the middle set of columns in Table 3. Panel $B$ reveals the same inferences as Table 3 regarding NIneg ${ }^{\wedge}$, NIneg ${ }^{\wedge} \times$ RegCapLow $^{\wedge}$, and $\mathrm{NIpos}^{\wedge}$, in that their coefficients are significantly positive, negative, and negative (tstats. $=5.03,-3.19$, and -6.77). However, the RegCapLow^ ${ }^{\wedge}$ coefficient is significantly positive in panel B (t-stat. $=2.04)$, whereas it is positive but insignificantly different from zero in Table 3 (t-stat. $=1.43)$.

\subsubsection{Using trading securities to manage earnings and regulatory capital}


As section 2 explains, we do not expect banks to manage earnings or regulatory capital using trading securities. Thus, as a validity check, we re-estimate Eq. (1) using fair value gains and losses on trading securities as the dependent variable and redefining $\mathrm{NI}$ and RegCapLow to be before fair value gains and losses rather than before RGL. Of the 4561 observations with non-zero trading securities, 4389 have trading gains and losses. The untabulated findings reveal no evidence of earnings or regulatory capital management using trading securities. In Models I and II of Table 2, t-statistics for the revised $\mathrm{NI}$ coefficients are 1.41 and 0.95 , and t-statistics for the RegCapLow coefficients are -0.80 and -1.07 . As in Table 2, the NIXRegCapLow coefficient is not significantly different from zero $(\mathrm{t}$-stat. $=1.25)$.

To ensure that these findings are attributable to trading securities gains and losses and not to sample composition, we also re-estimate Eq. (1) on this sample using RGL as the dependent variable. Untabulated statistics reveal that the RegCapLow coefficients are positive as predicted but-perhaps because of reduced power associated with the smaller sample size-not significantly different from zero. As in Table 2, the NIXRegCapLow coefficient is not significantly different from zero, and the $\mathrm{NI}$ coefficients are significantly negative (t-stats. $=-3.05$ and -2.56 ). The $\mathrm{NI}$ coefficient findings are consistent with those in Table 2 in revealing evidence of earnings smoothing using RGL.

\subsubsection{Alternative earnings management benchmark}

Although our tests implicitly assume that the benchmark for earnings management is net income before realized gains and losses on AFS securities, there could be other benchmarks. As an alternative, we consider the median net income for all banks. ${ }^{27}$ We estimate Eqs. (1) and (2) using [ $\mathrm{NI}-\mathrm{mNI}$ ] in place of $\mathrm{NI}$, where $\mathrm{mNI}$ is the median of net income before taxes for all banks in quarter $t$.

Untabulated findings related to Eq. (1) but using the alternative benchmark reveal inferences regarding earnings smoothing identical to those revealed by Table 2 . The untabulated $[\mathrm{NI}-\mathrm{mNI}$ ] coefficients are significantly negative (tstats. $=-3.60$ and -3.54); the untabulated RegCapLow coefficients are significantly positive (t-stats. = 1.86 and 1.78), and the untabulated RegCapLow $\times[\mathrm{NI}-\mathrm{mNI}]$ coefficient is not significantly different from zero (t-stat. $=-0.87$ ). Untabulated findings relating to Eq. (2) generally reveal the same inferences as those based on Table 3. One exception

\footnotetext{
${ }^{27}$ We do not use analyst earnings forecasts because analyst forecasts are not available for many banks, particularly non-listed ones. We do not use the $8 \%$ required regulatory capital ratio because, as footnote 13 explains, few observations have regulatory capital before RGL and taxes less than $8 \%$.
} 
is that the neg[ $\mathrm{NI}-\mathrm{mNI}]$ coefficients are not significantly different from zero in all three models (t-stats. $=-1.38,-0.82$, and 0.27 ), which reveals that the extent of earnings management for banks below this benchmark depends on the bank's UG, $\mathrm{UL}$, and RegCapLow. Another exception is that in Model III the pos[NI- $\mathrm{mNI}] \times \mathrm{UL}_{\mathrm{t}-1}$ coefficient is not significantly different from zero (t-stat. $=1.34$ ), which reveals that partitioning positive $\mathrm{NI}$ banks into those above and below median $\mathrm{NI}$ eliminates the unpredicted significantly negative coefficient in Table 3.

\subsubsection{Depositors as earnings management incentives for non-listed banks}

The incentive for non-listed banks to engage in earnings management could stem from depositors (Beatty et al. 2002). Thus, we re-estimate the Table 5, panel A, specifications for non-listed banks after including Dep, the bank's deposit liability deflated by total assets, and its interaction with NI and RegCapLow, individually and together. Untabulated findings reveal that the earnings smoothing we observe in Table 2 for non-listed banks stems from incentives relating to depositors. The Dep $\times \mathrm{NI}$ coefficients are significantly negative (t-stats. $=-5.81$ and -5.97$)$, and the $\mathrm{NI}$ coefficients are significantly positive (t-stats. $=4.27$ and 4.41 ). 


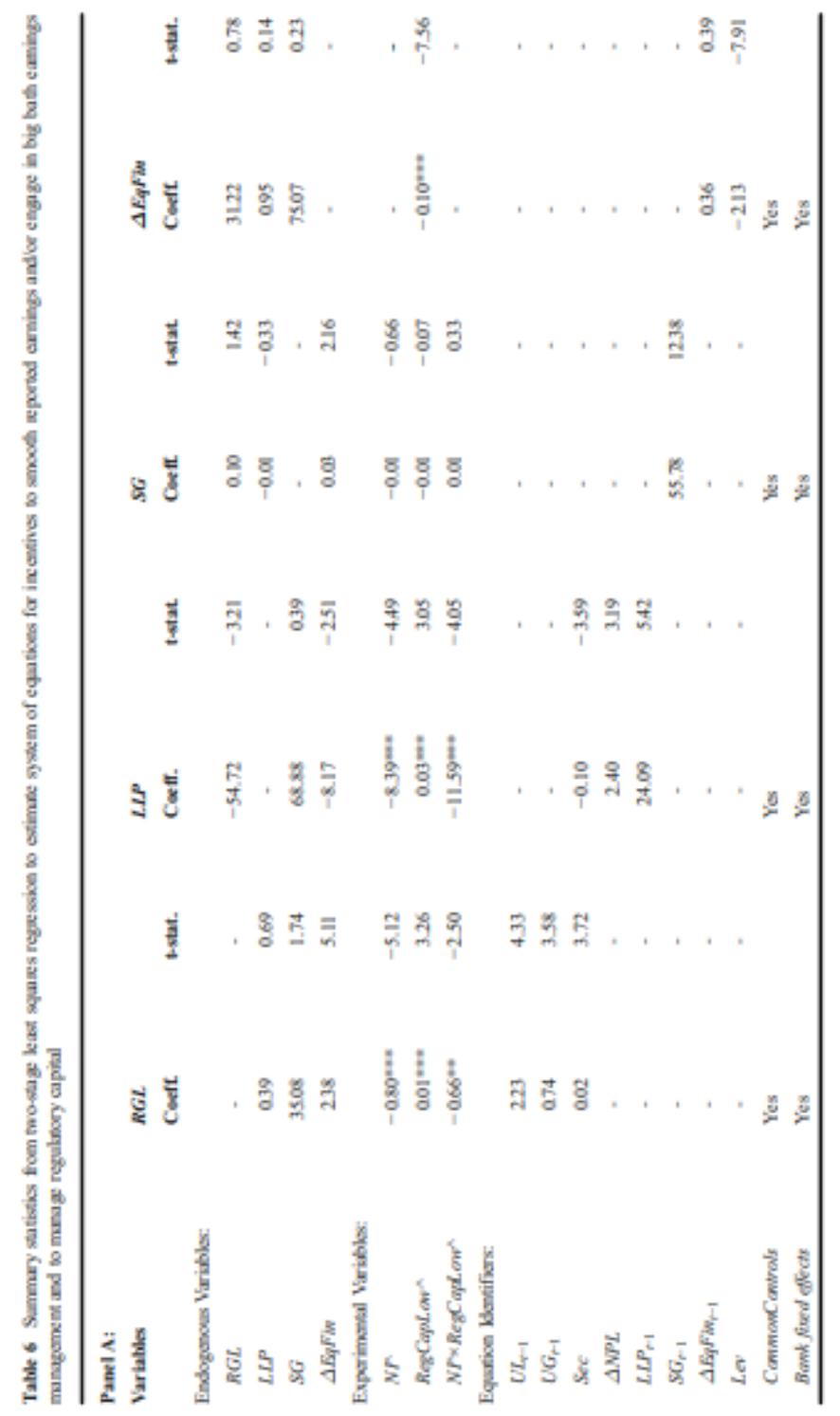




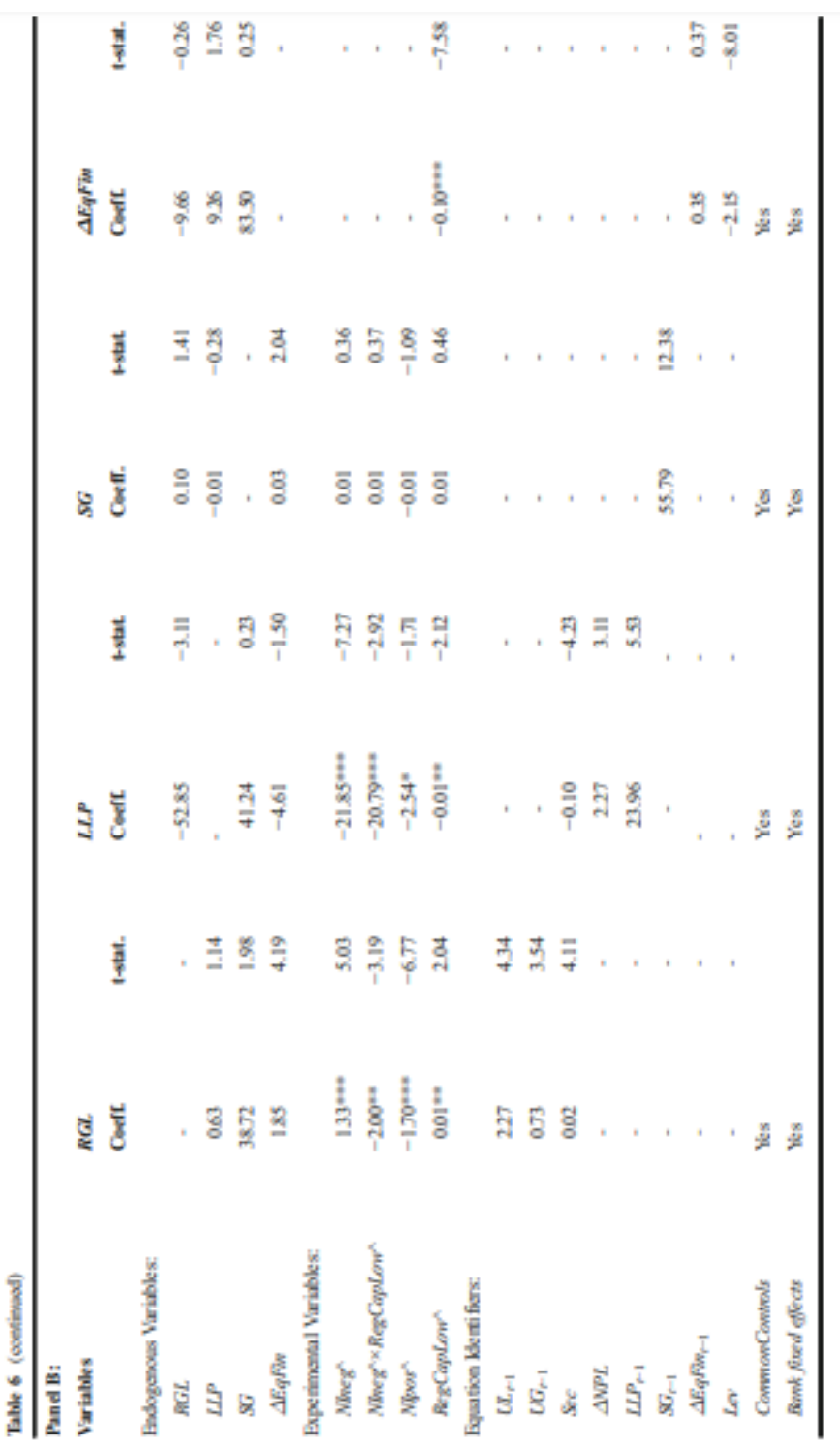




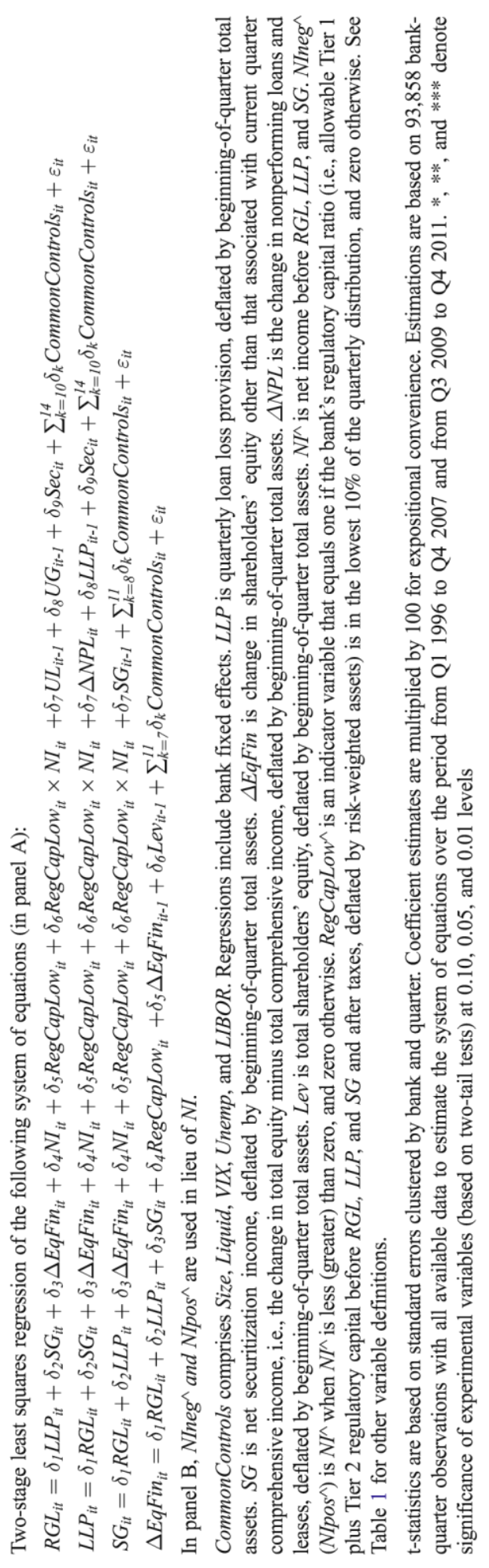




\section{${ }_{6}$ Conclusion}

The question we address is the extent to which, and how, banks use realized gains and losses on available for sale (AFS) securities to manage earnings and regulatory capital. AFS securities gains and losses are recognized in earnings and, largely, in regulatory capital only when they are realized. We base our inferences relating to earnings management on a large sample of publicly listed and non-listed banks from 1996 to 2011 and on estimations of the relations between realized gains and losses on AFS securities and earnings and regulatory capital, each calculated before the effect of the gains and losses. We find robust evidence consistent with banks using realized AFS securities gains and losses to smooth earnings and increase low regulatory capital. We also find evidence consistent with banks with negative earnings avoiding or reducing losses or engaging in big bath earnings management, with regulatory capital constraining big bath earnings management. The extent to which banks use realized AFS securities gains and losses to manage earnings and regulatory capital depends on their circumstances, including the extent to which they have unrealized gains and losses to realize. Our findings generally apply to listed and non-listed banks, which indicates that incentives to manage earnings and regulatory capital are not limited to banks whose equity trades in public capital markets. Findings from several additional analyses support our inferences, including the absence of evidence that banks use fair value gains and losses on trading securities to smooth earnings.

Our findings reveal that banks opportunistically use the discretion afforded to them by accounting standards and regulatory requirements and selectively realize AFS securities gains and losses to manage earnings and regulatory capital in a variety of ways. From a policy perspective, our findings suggest that including unrealized AFS securities gains and losses in regulatory capital and earnings would eliminate these incentives. Recent banking regulation has taken steps in this direction by requiring the largest, most sophisticated banks to include unrealized AFS securities gains and losses in regulatory capital. Our findings reveal that the inclusion of these gains and losses in other comprehensive income does not eliminate the incentive for banks to use realized AFS securities gains and losses to manage earnings. Rather, our findings suggest that recognizing these gains and losses in earnings-similar to the treatment of unrealized gains and losses on trading securities - is necessary to remove this incentive and, thus, eliminate realized AFS securities gains and losses as an earnings management tool. 
Acknowledgements We appreciate the helpful comments and suggestions from Michael Minnis, Doron Nissim, Stephen Penman, and seminar participants at the American Accounting Association annual meeting, especially John McInnis the discussant; Barcelona Accounting Seminar Series; European Accounting Association Annual Congress; Spanish Finance Association annual conference, especially Ricardo Gimeno the discussant; Universidad de Navarra; University of Neuchatel; Universitat Pompeu Fabra; Universidad de Valladolid; and the VII International Research Symposium for Accounting Academics (Madrid), especially Pedro J. García the discussant. We also appreciate the data collection efforts of Min Ji Lee. Germán LópezEspinosa (Javier Gomez-Biscarri) acknowledges financial support from the Ministerio de Ciencia e Innovación project ECO2012-33619 (ECO-2014-55488-P \& SEV-20150563) and from the Gobierno de Navarra Jerónimo de Ayanz program (Barcelona GSE).

\title{
Appendix
}

Table 7 Variable definitions

\author{
Variable Definition \\ RGL Realized gains and losses on available for sale (AFS) securities, \\ deflated by beginning-of-quarter total assets \\ $\mathrm{NI} \quad$ Net income before taxes and RGL, deflated by beginning-of-quarter \\ total assets \\ NIpos $\mathrm{NI}$ when $\mathrm{NI}$ is greater than or equal to zero, and zero otherwise \\ NIneg $\mathrm{NI}$ when $\mathrm{Nl}$ is less than zero, and zero otherwise \\ RegCap Regulatory capital ratio, i.e., allowable Tier 1 plus Tier 2 \\ regulatory capital before RGL and after taxes, deflated by risk- \\ weighted assets \\ UG Accumulated unrealized gains on AFS securities, deflated by total \\ assets \\ UL Accumulated unrealized losses on AFS securities, deflated by total \\ assets \\ Size Natural logarithm of beginning-of-quarter total assets \\ Sec Total securities, deflated by beginning-of-quarter total assets \\ Liquid Total liquid assets, deflated by beginning-of-quarter total assets \\ VIX Implied volatility of options on the S\&P 500 Index \\ Unemp One-year-ahead consensus forecast of the US unemployment rate \\ LIBOR Difference between the London Interbank Offer Rate and \\ overnight indexed swap rates \\ LLP Quarterly loan loss provision, deflated by beginning-of-quarter \\ total assets
}

$\Delta$ EqFin Change in shareholders' equity other than that associated with current quarter comprehensive income, i.e., the change in total 
equity minus total comprehensive income, deflated by beginning-of-quarter total assets

SG Securitization gains, i.e., net securitization income, deflated by beginning-of-quarter total assets

$\triangle N P L \quad$ Change in nonperforming loans and leases, deflated by beginningof-quarter total assets

Lev Total shareholders' equity deflated by total assets

$\mathrm{NI}^{\wedge} \quad$ Net income before RGL, LLP, and SG

RegCap^ Regulatory capital before RGL, LLP, and SG

\section{References}

Ahmed, A. S., Takeda, C., \& Thomas, S. (1999). Bank loan loss provisions: A re-examination of capital management, earnings management and signalling effects. Journal of Accounting and Economics, 28, $1-25$.

Amel-Zadeh, A., Barth, M. E., \& Landsman, W. R. (2017). The contribution of bank regulation and fair value accounting to procyclical leverage. Forthcoming, Review of Accounting Studies.

Bamber, L., Jiang, J., Petroni, K., \& Wang, I. (2010). Comprehensive income: Who's afraid of performance reporting? The Accounting Review, 85, 97-126.

Barth, M. E. (1994). Fair value accounting: Evidence from investment securities and the market valuation of banks. The Accounting Review, 69, 1-25.

Barth, M. E., Beaver, W. H., \& Wolfson, M. A. (1990). Components of earnings and the structure of bank share prices. Financial Analysts Journal, 56, 53-60.

Beatty, A., \& Harris, D. G. (1998). The effects of taxes, agency costs and information asymmetry on earnings management: A comparison of public and private firms. Review of Accounting Studies, 3, 299326.

Beatty, A., \& Liao, S. (2014). Financial accounting in the banking industry: A review of the empirical literature. Journal of Accounting and Economics, 58, 339-383.

Beatty, A., Chamberlain, S., \& Magliolo, J. (1995). Managing financial reports of commercial banks: The influence of taxes, regulatory capital and earnings. Journal of Accounting Research, 33, 231-261.

Beatty, A., Ke, B., \& Petroni, K. (2002). Differential earnings management to avoid earnings declines and losses across publicly and privately held banks. The Accounting Review, 77, 547-570.

Biddle, G., \& Choi, J. (2006). Is comprehensive income useful? Journal of Contemporary Accounting and Economics, 2, 1-32.

Burgstahler, D., \& Dichev, I. (1997). Earnings management to avoid earnings decreases and losses. Journal of Accounting and Economics, 24, 99-126.

Burgstahler, D., Hail, L., \& Leuz, C. (2006). The importance of reporting incentives: Earnings management in European private and public firms. The Accounting Review, 81, 983-1016.

Collins, J., Shackelford, D., \& Wahlen, J. (1995). Bank differences in the coordination of regulatory capital, earnings and taxes. Journal of Accounting Research, 33, 263-291.

Coppens, L., \& Peek, E. (2005). An analysis of earnings management by european private firms. Journal of International Accounting, Auditing and Taxation, 14, 1-17.

Dechow, P. M., \& Shakespeare, C. (2009). Do managers time securitization transactions to obtain accounting benefits? The Accounting Review, 84, 99-132. 
Dechow, P., Ge, W., \& Schrand, C. (2010a). Understanding earnings quality: A review of the proxies, their determinants and their consequences. Journal of Accounting and Economics, 50, 344-401.

Dechow, P., Myers, L., \& Shakespeare, C. (2010b). Fair value accounting and gains from asset securitizations: A convenient earnings management tool with compensation side-benefits. Journal of Accounting and Economics, 49, 2-25.

Degeorge, F., Patel, J., \& Zeckhauser, R. (1999). Earnings management to exceed thresholds. The Journal of Business, 72, 1-33.

Dhaliwal, D., Subramanyam, K. R., \& Trezevant, R. (1999). Is comprehensive income superior to net income as a measure of firm performance? Journal of Accounting and Economics, 26, 43-67.

Dong, M., \& Zhang, X. (2015). Selective trading of available-for-sale securities: Evidence from U.S. Commercial banks. Working paper University of Lausanne and University of California, Berkeley.

Dong, M., Ryan, S., \& Zhang, X. (2014). Preserving amortized cost within a fair-value-accounting framework: Reclassification of gains and losses on available-for-sale securities upon realization. Review of Accounting Studies, 19, 242-280.

Financial Accounting Standards Board. (1993). Statement of Financial Accounting Standards No. 115: Accounting for certain investments in debt and equity securities. Norwalk: FASB.

Financial Accounting Standards Board. (1995). Special Report, A guide to implementation of statement 115 on accounting for certain investments in debt and equity securities, questions and answers. Norwalk: FASB. Financial Accounting Standards Board. (1997). Statement of Financial Accounting Standards No. 130: Reporting comprehensive income. Norwalk: FASB.

Goel, A. M., \& Thakor, A. (2003). Why do firms smooth earnings? Journal of Business, 76, 151-192.

Gow, I. D., Ormazabal, G., \& Taylor, D. J. (2010). Correcting for cross-sectional and time-series dependence in accounting research. The Accounting Review, 85, 483-512.

Graham, J., Harvey, C., \& Rajgopal, S. (2005). The economic implications of corporate financial reporting. Journal of Accounting and Economics, 40, 3-73.

Healy, P. M., \& Wahlen, J. M. (1999). A review of the earnings management literature and its implications for standard setting. Accounting Horizons, 13, 365-383.

Hirst, E. D., \& Hopkins, P. E. (1998). Comprehensive income reporting and analysts' valuation judgments. Journal of Accounting Research, 36, 47-75.

Hope, O. K., Thomas, W. B., \& Vyas, D. (2013). Financial reporting quality of U.S. Private and public firms. The Accounting Review, 88, 1715-1742.

Karaoglu, N. E. (2005). Regulatory capital and earnings management in banks: The case of loan sales and securitizations. Working paper, FDIC Center for Financial Research.

Kilic, E., Lobo, G., Ranasinghe, T., \& Sivaramakrishnan, K. (2013). The impact of SFAS 133 on income smoothing by banks through loan loss provisions. The Accounting Review, 88, 233-260.

Laux, C., \& Leuz, C. (2010). Did fair-value accounting contribute to the financial crisis? Journal of Economic Perspectives, 24, 93-118.

Lifschutz, S. (2002). The effect of SFAS 115 on earnings management in the banking industry. The Journal of Applied Business Research, 18, 1-11.

Nissim, D., \& Penman, S. H. (2007). Fair value accounting in the banking industry, Center for Excellence in Accounting and Security Analysis Occasional Paper Series, Columbia Business School.

Pérez, D., Salas-Fumás, V., \& Saurina, J. (2008). Earnings and capital management in alternative loan loss provision regulatory regimes. European Accounting Review, 17, 423-445.

Petersen, M. (2009). Estimating standard errors in finance panel data sets: Comparing approaches. Review of Financial Studies, 22, 435-480. 
Scholes, M., Wilson, G. P., \& Wolfson, M. (1990). Tax planning, regulatory capital planning and financial reporting strategy for commercial banks. Review of Financial Studies, 3, 625-650.

Wall, L. D., \& Koch, T. W. (2000). Bank Loan-loss accounting: A review of theoretical and empirical evidence. Federal Reserve Bank of Atlanta, Economic Review, 85, 1-19.

Warfield, T., \& Linsmeier, T. (1992). Tax planning, earnings management, and the differential information content of bank earnings components. The Accounting Review, 67, 546-562. 